\title{
Comparative in Vitro Cytotoxicity Study of Silver Nanoparticle on Two Mammalian Cell Lines
}

\author{
Gordon Chambers \\ Technological University Dublin, Gordon.chambers@tudublin.ie \\ Sanchali Mukherjee \\ Technological University Dublin \\ Alan Casey \\ Technological University Dublin, alan.casey@tudublin.ie
}

See next page for additional authors

Follow this and additional works at: https://arrow.tudublin.ie/scschphyart

Part of the Biochemistry, Biophysics, and Structural Biology Commons

\section{Recommended Citation}

Mukherjee, SG., O'Claonadh, N., Casey, A., and Chambers G. Comparative in vitro cytotoxicity study of silver nanoparticle on two mammalian cell lines. Toxicol In Vitro. Mar; 26(2):238-51(2012) doi:10.1016/ j.tiv.2011.12.004

This Article is brought to you for free and open access by the School of Physics \& Clinical \& Optometric Science at ARROW@TU Dublin. It has been accepted for inclusion in Articles by an authorized administrator of ARROW@TU Dublin. For more information, please contact arrow.admin@tudublin.ie, aisling.coyne@tudublin.ie, gerard.connolly@tudublin.ie.

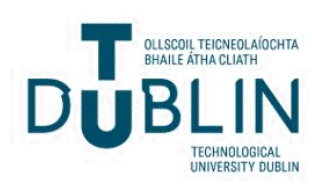


Authors

Gordon Chambers, Sanchali Mukherjee, Alan Casey, and Niall Ó Claonadh

This article is available at ARROW@TU Dublin: https://arrow.tudublin.ie/scschphyart/26 


\title{
Comparative in vitro cytotoxicity study of silver nanoparticle on two mammalian cell lines
}

\author{
Sanchali Gupta Mukherjee ${ }^{\mathrm{a}, \mathrm{b}, *}$, Niall O'Claonadh ${ }^{\mathrm{a}}$, Alan Casey ${ }^{\mathrm{a}}$, Gordon Chambers ${ }^{\mathrm{a}, \mathrm{b}}$ \\ ${ }^{a}$ Nanolab Research Centre, Focas Institute, Dublin Institute of Technology, Kevin Street, Dublin 8, Ireland \\ ${ }^{\mathrm{b}}$ School of Physics, Dublin Institute of Technology, Kevin Street, Dublin 8, Ireland
}

Keywords:

Physical characterization

Cytotoxicity assessment

Mitochondrial metabolism

Alamar Blue assay

Coomassie Blue assay

Lysosomal activity

Cellular proliferative capacity

LD50

ROS

Glutathione

Adenylate kinase

Apoptosis

Comparative cytotoxicity

\begin{abstract}
A B S T R A C T
In this study the cytotoxic effect of commercially available silver $(\mathrm{Ag})$ nanoparticle was evaluated using human dermal and cervical cancer cell lines. Prior to the cellular studies a full particle size characterisation was carried out using Dynamic Light Scattering (DLS), Transmission Electron Microscopy and Scanning Electron Microscopy in distilled water and cell culture media. The Zeta Potential (ZP) associated with the $\mathrm{Ag}$ nanoparticle was also determined in order to assess its stability in the solutions and its possible interaction with the media. The DLS and ZP study have suggested interaction of Ag nanoparticles with the media, which can lead to secondary toxicity. The toxic effects of Ag nanoparticles were then evaluated using different cytotoxic endpoints namely the lysosomal activity, mitochondrial metabolism, basic cellular metabolism, cellular protein content and cellular proliferative capacity. The cytotoxic effect of $\mathrm{Ag}$ nanoparticle was dependant on dose, exposure time and on the cell line tested. Further investigation was carried out on HeLa and HaCaT cell lines to elucidate the mechanism of its cytotoxicity. The Ag nanoparticle was noted to induce elevated levels of oxidative stress, glutathione depletion and damage to the cell membrane as found from the adenylate kinase assay and that leads to the apoptosis. Overall, significant differences were observed between the sensitivity of the two cell lines which can be understood in terms of their natural antioxidant levels.
\end{abstract}

\section{Introduction}

Silver (Ag) nanoparticles offer remarkably different physiochemical and biological characteristics from that of bulk silver, such as increased optical, electromagnetic, catalytic properties and antimicrobial activity (Choi et al., 2009). Ag has traditionally been used as an antimicrobial agent for many years. Ag displays an oligodynamic effect which is an inherent antimicrobial property associated with mainly heavy metals (Shuval et al., 1995). The exact mechanism by which this occurs is still largely unknown however, some literature proposes that $\mathrm{Ag}$ interacts with the thiol groups on proteins necessary for microbial respiration (Cho et al., 2005). Ag ions are seen to actively seek out the thiol groups of proteins and enzymes thus making them unsuitable for microbial development (Liau et al., 1997). Ag has also been shown to directly interact with the cell membranes of bacteria causing breaks in the membrane and the cell to essentially burst (Percival et al., 2005). It is this innate property that has lead to an array of potential appli-

* Corresponding author at: Nanolab Research Centre, Focas Institute, Dublin Institute of Technology, Kevin Street, Dublin 8, Ireland. Tel.: +353 14027933; fax: +3534027901.

E-mail address: sanchali.guptamukherjee@student.dit.ie (S.G. Mukherjee). cations of $\mathrm{Ag}$ nanoparticles in both the medical arena and consumer products.

In terms of medical applications $\mathrm{Ag}$ nanoparticles has found applications in wound dressings, contraceptive devices, surgical instruments and bone prostheses which can be coated or embedded with the Ag nanoparticles (Cheng et al., 2004; Chen et al., 2006; Muangman et al., 2006; Cohen et al., 2007; Lansdown, 2006; Zhang and Sun, 2007). In addition, consumer products containing Ag nanoparticles include antibacterial room spays, laundry detergents, water purificants and wall paint (Cheng et al., 2004; Zhang and Sun, 2007). Ag nanoparticles are also incorporated into textiles for manufacture of clothing, undergarments and socks (Lee et al., 2007; Vigneshwaran et al., 2007).

As a result of these applications exposure of $\mathrm{Ag}$ nanoparticles to us and our environment are becoming increasingly widespread. Consequently, silver in the form of nanoparticles has gained an increasing access to tissues, cells and biological molecules within the human body. Once reaching nanoscale, certain materials do exhibit significant toxicity to mammalian cells even if they are biochemically inert and biocompatible in bulk size, e.g. carbon (Magrez et al., 2006; Shvedova et al., 2005). Several studies exist in literature showing that the release of $\mathrm{Ag}$ ions inhibit the normal respiratory functions of the cells and cause cell death. A study 
carried out by Hussain et al. (2005) have shown that Ag nanoparticles was cytotoxic to rodent liver cells causing them to change morphologically and also interfering with mitochondrial function. It has also been shown that $\mathrm{Ag}$ nanoparticles are highly toxic to the osteoblast cell lines (Moaddab et al., 2011). One study has shown a very high toxic response of $\mathrm{Ag}$ nanoparticle of 5-10 nm diameter on hepatoma cell line, HepG2, by causing oxidative stress and DNA damage (Kim et al., 2009).

The human body has several semi-open interfaces for direct substance exchange with the environment, i.e. the respiratory tract, gastrointestinal tract (GIT) and skin. In view of Ag nanoparticle's diverse forms of existence, they are also the principle routes of exposure. The irreversible pigmentation of skin and/or eye, i.e. argyria or argyrosis, due to the silver deposition, may develop after prolonged exposure to silver or silver compounds (Van deVoorde et al., 2005; Eturska and Obreshkova, 1979; Spencer et al., 1980). Female genital tract is also an entryway of potential importance since Ag nanoparticles has been incorporated into maternal hygiene products (Cheng et al., 2004; Zhang and Sun, 2007). At these sites, nanoparticles can undergo a series of processes like binding and reacting with proteins, phagocytosis, deposition, clearance and translocation. On the other hand nanoparticles can elicit a spectrum of tissue responses such as cell activation, generation of Reactive Oxygen Species (ROS), inflammation and cell death (Chen et al., 2006; Xia et al., 2006; Ahn et al., 2005).

Therefore, the wide range of applications of $\mathrm{Ag}$ nanoparticles could potentially result in multiple sites of exposure to Ag nanoparticles and studies into their biological effects are of great importance. The aim of this study is to examine the effects of $\mathrm{Ag}$ nanoparticles on cell models of two possible routes of entry and exposure for this two human cell lines were employed - a dermal cell line and a cervical cancerous cell line. The effect has been evaluated using variety of end-points to postulate a mechanism of action of Ag nanoparticles. A battery of standard cytotoxicity assays, viz., Alamar Blue (AB) assay, Neutral Red (NR) assay, MTT assay, Coomassie Blue (CB) assay, were employed to study the effect of $\mathrm{Ag}$ nanoparticles on both the cell lines. AB, NR, CB and MTT assays show the effect of Ag nanoparticle on different aspects of cellular activity. Therefore the interpretation of the dose response from these assays is very important to understand the cellular response upon $\mathrm{Ag}$ nanoparticle exposure.

The interpretation of the action of the $A B$ assay is somewhat varied. One report has suggested that it may indicate the early inhibition of cytoplasmic metabolism and cell growth (O'Brien et al., 2000) while another suggests that it indicates the inhibition of mitochondrial metabolism (De Fries and Mitsuhashi, 1995). But in general it is suggested that it shows basic cellular metabolism in terms of it oxido-reductase enzyme activity (Mukherjee et al., 2010b). NR is a colorimetric assay for the quantification of the membrane permeability and lysosomal activity of cells in response to pharmaceutical, chemical and environmental compounds, and nutrients (Mukherjee et al., 2010a,b). The CB assay quantifies the amount of protein present in the cells (Clare and Cormack, 1996). The MTT colorimetric assay determines the ability of viable cells to reduce the soluble, yellow tetrazolium salt [3-(4,5-dimehtylthiazol-2-yl)-2,5-diphenyltetrazolium bromide] (MTT) into an insoluble, purple formazan. Tetrazolium salts accept electrons from oxidized substrates or enzymes, such as NADH and NADPH. Reduction of MTT takes place at the ubiquinone and cytochrome $b$ and $c$ sites of the mitochondrial electron transport chain due to succinate dehydrogenase activity (Mosmann, 1983). The reduction of MTT to formazan within cells helps in the estimation of the mitochondrial metabolism and hence the number of viable cells after exposure to nanoparticles. Apart from accessing the effect of Ag nanoparticle on different cellular organelles and metabolism, we have also accessed its effect on the cellular proliferative capacity by clonogenic assay. Intracellular reactive oxygen species (ROS) generation, glutathione (GSH) depletion, adenylate kinase (AK) release from the cells and apoptosis induction upon Ag nanoparticle exposure was also studied. Adenylate kinase (also known as ADK or myokinase) is a phosphotransferase enzyme that catalyzes the nucleotide phosphoryl exchange reaction 2ADP $\leftrightarrow$ AT$P+A M P$, critical in cell life. They are found in cytosol and mitochondria of the cells. Adenylate kinase will only leak from cells whose cell membrane integrity has been compromised. Apoptosis is an energy driven process; ATP levels are maintained in metabolically active cells, but upon cell death residual ATP is degraded (Bradbury et al., 2000; Crouch et al., 1993). With the onset of apoptosis, cells show an increase in the levels of cellular ADP (adenosine diphosphate) but without an appreciable drop in ATP. As cells pass into secondary necrosis the ADP levels continue to rise as hydrolysis of ATP starts to occur. In primary necrosis ATP levels fall rapidly as a result of exposure to high concentrations of toxic agents with a corresponding increase in the cellular ADP (Bradbury et al., 2000). Finally the differences between the responses from the two cell lines are compared and the possible reason behind the difference in the responses is elucidated.

\section{Materials and methods}

\subsection{Test materials and reagents}

Silver (Ag) nanopowder of $<100 \mathrm{~nm}$ was purchased from Sigma Aldrich Ltd. (Dublin, Ireland). 3-(4,5-Dimethylthiazol-2-yl)-2,5diphenyltetrazolium bromide (MTT), Neutral Red (NR), Commassie Blue (CB) and 2',7'-dichlorofluorescin diacetate (DCF) as well as cell culture media, supplements, the trypsinisation solution were all purchased from were purchased from Sigma Aldrich Ltd. (Ireland). Alamar Blue ${ }^{\mathrm{TM}}(\mathrm{AB})$ was purchased from Biosciences (Dublin, Ireland). Carbol fuchsin was purchased from BDH (UK). ToxiLight ${ }^{\mathrm{TM}}$ and ApoGlow ${ }^{\circledR}$ kit were purchased from Lonza Ltd. (Wokingham, UK).

\subsection{Cell culture}

HaCaT cells, an immortal non-cancerous human keratinocyte cell line (kindly provided by Prof. Dr. Boukamp, Heidelberg), HeLa cells (ATCC, CCL-2 ${ }^{\mathrm{TM}}$ ) an epithelial adenocarcinoma cell line of the cervix were employed in this study. HaCaT cells were cultured in Dulbecco's Modified Eagle's Medium Nutrient Mixture F-12 HAM (DMEM F-12 HAM) with $2 \mathrm{mM}$ L-glutamine supplemented with $10 \%$ fetal bovine serum (FBS), $45 \mathrm{IU} / \mathrm{ml}$ penicillin and $45 \mathrm{IU} / \mathrm{ml}$ streptomycin (HaCaT media) at $37^{\circ} \mathrm{C}$ in $5 \% \mathrm{CO}_{2}$. HeLa cells were cultured in RPMI-1640 medium supplemented with 10\% FBS, $45 \mathrm{IU} / \mathrm{ml}$ penicillin and $45 \mathrm{IU} / \mathrm{ml}$ streptomycin (HeLa media) at $37^{\circ} \mathrm{C}$ in $5 \% \mathrm{CO}_{2}$.

\subsection{Characterization of Ag nanoparticles}

Prior to the cytotoxicity testing Ag nanoparticles were subjected to an extensive characterisation process, where possible measurements were performed on $\mathrm{Ag}$ nanoparticle as purchased and on test suspensions of them. The suspensions of $\mathrm{Ag}$ nanoparticles were prepared in distilled water $\left(\mathrm{dH}_{2} \mathrm{O}\right)$, HaCaT media and in HeLa media using bath-sonicator (Degussa-Ney ULTRAsonik 57X, 50/ $60 \mathrm{~Hz}$, California, USA) prior to size and zeta potential measurements. Dynamic light scattering sizing measurements and zeta potential measurements were performed with the aid of a Malvern Zeta Sizer Nano ZS (Malvern Instruments, Worcestershire, UK) operating with version 5.03 of the systems Dispersion Technology Software (DTS Nano). For size measurement, DTS0012 disposable 
sizing cuvettes were used. The refractive index (RI) of Ag nanoparticles, $\mathrm{dH}_{2} \mathrm{O}$, HaCaT media and HeLa media were 1.6, 1.330, 1.332, 1.300 , respectively. Prior to analysis, viscosity measurements were performed on all media and $\mathrm{dH}_{2} \mathrm{O}$ with the aid of a Viscometer SV10 (A\&D Instruments Ltd., UK) at $25{ }^{\circ} \mathrm{C}$ and the recorded values used in all DLS size estimations. The viscosity of $\mathrm{dH}_{2} \mathrm{O}$, HaCaT media and HeLa media at $25^{\circ} \mathrm{C}$ were $0.887 \mathrm{cP}, 0.82 \mathrm{cP}, 0.550 \mathrm{cP}$, respectively. The samples were equilibrated at $25^{\circ} \mathrm{C}$ for $3 \mathrm{~min}$ before each measurement. For zeta potential measurements DTS1060C clear disposable zeta cells were used and the measurements were performed at $5 \mathrm{~V}$. Smoluchowski equation was used in the DTS software to calculate the zeta potential of the Ag nanoparticles. For all zeta potential measurements analysis was performed on the solutions with the automatic model setting, using an applied voltage of $5 \mathrm{~V}$, to minimize artefacts and charring of media proteins during analysis. The specific surface area of the particles was estimated with a Micrometrics GEMINI BET. BET sample holders were filled with a known mass of the powdered $\mathrm{Ag}$ nanoparticles and measured. The sample was degassed for $2 \mathrm{~h}$ at room temperature with nitrogen gas prior to analysis, nitrogen gas was used as the absorptive gas, a multipoint method was used in the estimation of specific surface area and the sample was analysed without porosity analysis. transmission electron microscopy (TEM) was also used to estimate the size of the $\mathrm{Ag}$ nanoparticles from its images. The instrument used was a JEOL 100CX model TEM. Samples were prepared by dispersing Ag nanoparticles in ethanol to a concentration of $10 \mathrm{mg} / \mathrm{l}$ by sonication 750 watts Ultrasonic Processor tip (Branson Ultrasonics, Ultra sonic processor VCX$750 \mathrm{~W}$ ) sonicator at $40 \%$ amplitude for a total operating time of $45 \mathrm{~s}$.

Samples were then drop cast onto $3 \mathrm{~mm}$ FORMVAR coated $\mathrm{Cu}$ grids (AGAR Scientific). Once the solvent had evaporated particle size was measured at a range of magnifications up to 80,000 . The accelerating voltage and probe current used for TEM analysis were $25 \mathrm{kV}$ and $18 \mu \mathrm{A}$, respectively. SEM was also performed to analyse particle size. Hitachi SU 6600 FESEM instrument was used. The SEM was calibrated with Au on Carbon standard provided by Agar Scientific (Essex, UK). Sample preparation was identical to that of the TEM preparation. Solutions were drop cast onto a pure silicon wafer which had been thoroughly cleaned by sonication in acetone for a period of $30 \mathrm{~min}$ followed by boiling in propanol for $30 \mathrm{~min}$. The silicon wafers were then left to air dry in a dust free environment and the nanoparticle solution was drop casted onto them $24 \mathrm{~h}$ prior to measurement.

\subsection{Cytotoxicity evaluation}

The $A B, N R, C B$, MTT and the clonogenic assay were performed for assessment of the cytotoxicity of $\mathrm{Ag}$ nanoparticles to the two cell lines. A preliminary or range finding test was conducted to determine the range of concentrations of interest for the definitive test. The definitive test used a concentration range (at least eight concentrations) in which effects was likely to occur, thereby permitting the calculation of the respective Lethal Dose $\left(\mathrm{LD}_{50}\right)$, no observed effect concentration (NOEC) and lowest observed effect concentration (LOEC). In all cases, results were compared to an unexposed control, eliminating any dependence of cell line exposures on volumes, well type, seeding efficiency and numbers, exposure times, etc. A stock solution of Ag nanoparticle was prepared aseptically, from which different concentrations of Ag nanoparticles were prepared in the respective HaCaT media and HeLa cell culture media, followed by bath sonication (Degussa-Ney ULTRAsonik 57X, California, USA) for $10 \mathrm{~min}$ at room temperature before exposure. As a positive control, 10\% dimethyl sulfoxide (DMSO) prepared in the respective media was used parallel to the Ag nanoparticle exposures.

\subsubsection{Alamar Blue, Neutral Red and Coomassie Blue assays}

For the AB and NR assays, cells were seeded in 96 well microplates (Nunc, Denmark) at a density of $1 \times 10^{5}$ cells $/ \mathrm{ml}$ in $100 \mu \mathrm{l}$ of respective media containing $10 \%$ FBS. At least three independent experiments were conducted and six replicate wells were employed per concentration per plate in each independent experiment. After $24 \mathrm{~h}$ of cell attachment, plates were washed with $100 \mu \mathrm{l} /$ well PBS and the cells were treated with increasing concentrations of Ag nanoparticles, prepared in $10 \%$ FBS containing media for $24,48,72$ and $96 \mathrm{~h}$. All incubations were performed at $37^{\circ} \mathrm{C}$ in a $5 \% \mathrm{CO}_{2}$ humidified incubator.

The $A B, N R$ and $C B$ assays were conducted consecutively on the same set of plates. The $A B$ assay was performed first followed by the NR assay and then lastly the CB assay. The assays were carried out according to manufacturer's instruction. Briefly, control media or test exposures were removed; the cells were rinsed with PBS and $100 \mu$ lo $A B / N R$ medium $(5 \%[v / v]$ solution of $A B$ and $1.25 \%$ $[\mathrm{v} / \mathrm{v}]$ of NR dye) prepared in fresh media (without FBS or supplements) were added to each well. After $3 \mathrm{~h}$ incubation AB fluorescence was measured at the respective excitation and emission wavelength of $531 \mathrm{~nm}$ and $595 \mathrm{~nm}$ in a VICTOR ${ }^{3} \mathrm{~V}^{\text {TM }} 1420$ Multilabel Counter (Perkin Elmer, USA). Wells having only AB and media were used as blanks. After measurement, the wells were then washed with PBS and $100 \mu \mathrm{l}$ of NR fixative (50\% ethanol, $49 \%$ $\mathrm{dH}_{2} \mathrm{O}$ and $1 \%$ glacial acetic acid) was added to each well and the plates were shaken at $240 \mathrm{rpm}$ for $10 \mathrm{~min}$. The NR fluorescence was then measured at the excitation and emission wavelength of 531 and $642 \mathrm{~nm}$, respectively in the same instrument. Protein determinations were performed on the same plates immediately by $\mathrm{CB}$ assay following NR uptake study. Excess NR dye was removed from the cells by washing with $100 \mu$ l de-staining solution. COMMASSIE dye was added to each well and the plate agitated for $10 \mathrm{~min}$. The dye was removed and the plate washed with an acetic acid-ethanol solution. The wash solution was discarded and the dye extracted with measuring solution (1 $\mathrm{M}$ potassium acetate). The plate was shaken at $240 \mathrm{rpm}$ for $10 \mathrm{~min}$ and the absorbance of the extracted dye was read at $570 \mathrm{~nm}$ (reference filter $340 \mathrm{~nm}$ ) using the microplate reader. For these three assays, mean fluorescence/absorbance units for the six replicate cultures were calculated for each exposure treatment.

\subsubsection{MTT assay}

A parallel set of at least 3 replicate plates was set up for the MTT assay and seeded and exposed in an identical manner as described in Section 2.4.1. After 24, 48 and $72 \mathrm{~h}$ of Ag nanoparticle (AgNP) exposure, the medium for the control or test exposures was removed, the cells were washed with PBS and $100 \mu$ of freshly prepared MTT in media ( $5 \mathrm{mg} / \mathrm{ml}$ of MTT in media [without FBS or supplements]) were added to each well. After $3 \mathrm{~h}$ incubation, the medium was discarded and the cells were rinsed with PBS and $100 \mu \mathrm{l}$ of MTT fixative solution (isopropanol with $0.04 \mathrm{~N} \mathrm{HCl}$ ) were added to each well and the plates were shaken at $240 \mathrm{rpm}$ for $10 \mathrm{~min}$. The absorbance was then measured at $595 \mathrm{~nm}$ in a TECAN GENios (Grodig, Austria) plate reader.

\subsubsection{Clonogenic assay}

The clonogenic assay was developed by Puck and Marcus (1956) and further standardized by Franken et al. (2006). The clonogenic assay was performed in 6 well plates (Nunc, Denmark) and each well was seeded with $2 \mathrm{ml}$ of respective 10\% FBS containing media at a cell density of 250 cells/ml. For both cell lines, the cells were allowed to attach for $12 \mathrm{~h}$, which is shorter than their reported doubling time of $23 \mathrm{~h}$ for HaCaT cells (Boukamp et al. 1988) and $22 \mathrm{~h}$ for Hela cells (York and Majerus, 1994). Therefore it is assumed that predominantly single cells were present at the time of exposure. After $12 \mathrm{~h}$ of cell attachment, plates were washed 
with $2 \mathrm{ml} /$ well PBS and the cells were treated with increasing concentrations of AgNP prepared in 10\% FBS containing respective media. The plates were then incubated for 8 days. Two replicate wells were used for each control and test concentrations per 6-well plate. Following exposure, the test solution was removed; the cells were washed with PBS and finally fixed and stained with $20 \%$ carbol in formalin solution (BDH, Poole, UK). The colonies were then manually counted. The minimum size of a colony was considered to be 50 cells/colony. In all these assays 10\% DMSO in 10\% FBS supplemented media was used as a positive control parallel to the $\mathrm{Ag}$ nanoparticle test solutions.

\subsection{Optical microscopic study}

Interaction of $\mathrm{Ag}$ nanoparticles with $\mathrm{HaCaT}$ and HeLa cells lines was studied by optical microscopy. Both the cell lines were seeded at a density of $1 \times 10^{6}$ cells/ml in petri dishes (Nunc, Denmark) and the Petri dishes were kept in a $37^{\circ} \mathrm{C}, 5 \% \mathrm{CO}_{2}$ incubator. After $24 \mathrm{~h}$ of cell attachment, the cells were washed twice with PBS and were exposed to $50 \mathrm{mg} / \mathrm{l}, 100 \mathrm{mg} / \mathrm{l}$ and $200 \mathrm{mg} / \mathrm{l} \mathrm{Ag}$ nanoparticle concentrations in the respective media and the Petri dishes were kept in a $37^{\circ} \mathrm{C}, 5 \% \mathrm{CO}_{2}$ incubator for $24 \mathrm{~h}$. The Ag nanoparticle test solutions were prepared in the same way as stated in Section 2.4. Following exposure, the test solutions were removed; the cells were washed twice with PBS and were imaged in $37^{\circ} \mathrm{C}$ PBS using a Nikon Eclipse E600 microscope. All images were recorded using a Spot RT digital camera using Spot software (version 3.2.4, Diagnostic Instruments, Inc., USA).

\subsection{Reactive oxygen species (ROS) study}

Intracellular oxidative stress was quantified with the aid of $2^{\prime}, 7^{\prime}$-dichlorofluorescin diacetate (DCFH-DA), which was reported to detect intracellular hydroperoxides (Cathcart et al., 1983) and also a probe for wide range of reactive oxygen species (Invitrogen, Ireland, website - http://www.invitrogen.com/site/ us/en/home/References/Molecular-Probes-The-Handbook/tables/ Reactive-oxygen-species.html). Briefly, healthy confluent cells were harvested and seeded (1000 cells/well) into black bottomed 96 well plates (Nunc, Denmark) and allowed to attach for a period of $24 \mathrm{~h}$ prior to exposure. For ROS quantification three independent experiments were performed for each independent experiment eight replicate wells were used for control, eight replicate wells were employed for the positive control and eight replicate wells were used for each test concentration per microplate. A working stock of $20 \mu \mathrm{M}$ DCFH-DA in PBS was prepared and all test concentrations, unexposed negative controls and positive controls were prepared and exposed to the cells in this working stock. The negative control consisted of the working stock solely namely a $20 \mu \mathrm{M}$ DCFH-DA solution in PBS, the positive control consisted of a $1 \mu \mathrm{M}$ Hydrogen Peroxide $\left(\mathrm{H}_{2} \mathrm{O}_{2}\right)$ prepared in the $20 \mu \mathrm{M}$ DCFH-DA/PBS working stock solution and finally the test concentrations consisted of a concentration range of $\mathrm{Ag}$ nanoparticles (for HaCaT 7.81 to $125 \mathrm{mg} / \mathrm{l}$ and for HeLa $0.625-80 \mathrm{mg} / \mathrm{l}$ ) prepared in the working stock a $20 \mu \mathrm{M}$ DCFHDA/PBS solution.

After the initial $24 \mathrm{~h}$ attachment period the media was removed, the cells were subsequently washed with $100 \mu \mathrm{L}$ of PBS and treated with $100 \mu \mathrm{L}$ of the negative control, positive control and the test concentrations of AgNP and incubated for 30,60, $120,180,240,300 \mathrm{~min}$. The rate of intracellular oxidative stress was then monitored by monitoring the emission at $529 \mathrm{~nm}$ (by $504 \mathrm{~nm}$ excitation) of the DCFH-DA dye at various time intervals of 30-300 min (the exposure plates were re-incubated for the remaining time after each measurement had been recorded).

\subsection{Intracellular reduced glutathione level measurement}

A commercial kit ThiolTracker ${ }^{\mathrm{TM}}$ Violet was used to estimate the levels of intracellular reduced glutathione (GSH) in HaCaT cells upon AgNP exposure. The fluorescent dye can be used for intracellular GSH detection in flow cytometry or by fluorescent imaging in living cells (http://products.invitrogen.com/ivgn/product/ T10096? ICID=search-product). In this study, a fluorescence microplate reader was employed to quantify the fluorescence intensity of the dye and therefore the intracellular GSH levels in control and exposed HaCaT cultures. The study was performed in 96-well microplate format, wherein the cells were seeded at a density of $1 \times 10^{5}$ cells $/ \mathrm{ml}$ in $100 \mu \mathrm{l}$ of respective media containing $10 \%$ FBS. After $24 \mathrm{~h}$ of cell attachment, the cells were washed twice with $100 \mu \mathrm{l} /$ well PBS and were exposed to $25-200 \mathrm{mg} / \mathrm{l} \mathrm{AgNP}$ in $10 \%$ FBS supplemented media for $24 \mathrm{~h}$. 10\% DMSO in the respective media were also used as positive controls. Following exposure, the cells were washed with $100 \mu \mathrm{l} /$ well PBS and exposed to the ThiolTracker $^{\mathrm{TM}}$ Violet dye, prepared in PBS at a concentration of $20 \mu \mathrm{M}$ in $100 \mu \mathrm{l} /$ well and the plates were kept in a $37{ }^{\circ} \mathrm{C}, 5 \% \mathrm{CO}_{2}$ incubator for $30 \mathrm{~min}$. Following incubation, the dye solution was removed, the cells were washed thrice with $100 \mu \mathrm{l} /$ well PBS and the fluorescence was measured at excitation and emission wavelengths of 405 and $535 \mathrm{~nm}$, respectively, in a VICTOR3 V ${ }^{\text {TM}} 1420$ Multilabel Counter plate reader (Perkin Elmer, UK).

\subsection{Adenylate kinase (AK) release assay}

The bioluminescent ToxiLight ${ }^{\mathrm{TM}}$ kit (Lonza Ltd., Wokingham, UK) was employed to measure the concentration of AK present in the supernatants of test solutions after different time point exposures. The kit is based on the bioluminescent measurement of AK which is present in all cells. This kit quantitatively measures the release of AK from damaged cells. A loss of cell integrity, through damage to the plasma membrane, results in the leakage of a number of factors from cells cultured in vitro into the surrounding medium. The measurement of the release of AK from the cells allows the accurate and sensitive determination of cytotoxicity and cytolysis.

The reaction involves two steps. The first involves the addition of ADP as a substrate for AK. In the presence of the enzyme, AK, the ADP is converted to ATP for assay by bioluminescence:

$$
\mathrm{Mg}^{++} \mathrm{ADP}+\mathrm{ADP} \leftrightarrow \mathrm{Mg}^{++} \mathrm{ATP}+\mathrm{AMP}
$$

The bioluminescent method utilizes an enzyme luciferase, which catalyses the formation of light from ATP and luciferin according to the following reaction:

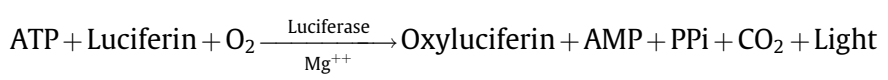

(Lonza Rockland, Inc., www.lonza.com.biotechserv@lonza.com).By combining the two reactions, the emitted light intensity is linearly related to the AK concentration.

To quantify AK release, the exposed test solutions from the $A B$, $\mathrm{NR}$ and $\mathrm{CB}$ assays were collected after their respective time point exposures and were stored at $-80^{\circ} \mathrm{C}$. Upon thawing, $20 \mu \mathrm{l}$ of each sample (which contained the pooled supernatants from six replicate treatments per plate) were removed and transferred to a 96-well white luminescence plate (Falcon, VWR Ireland) for AK measurement. Media was assayed in triplicate for AK release. AK Detection Reagent (AKDR) was then reconstituted in Assay Buffer supplied with a kit. Leave for $15 \mathrm{~min}$ at room temperature to ensure complete rehydration. One-hundred microlitres of AK detection reagent was then added to each well and the plate 
incubated at room temperature (RT) for $5 \mathrm{~min}$ and a $1 \mathrm{~s}$ integrated luminescence reading was recorded.

\subsection{Apoptosis study}

Ag nanoparticulate induce apoptosis was studied using ApoGlow $^{\circledR}$ kit of Lonza Ltd. (Wokingham, UK). In brief, $100 \mu$ l the cells were seeded in 96-well white luminescence plates (Falcon, VWR Ireland) at a density of $1 \times 10^{5}$ cells/ml in $100 \mu$ l of respective media. Following $24 \mathrm{~h}$ cell attachment, the plates were washed with $100 \mu \mathrm{l} /$ well PBS and the cells were treated with increasing concentrations of $\mathrm{Ag}$ nanoparticles, prepared in 10\% FBS containing media for $24 \mathrm{~h}$. All incubations were performed at $37{ }^{\circ} \mathrm{C}$ in a $5 \% \mathrm{CO}_{2}$ humidified incubator. Six replicate wells were used for each control and test concentrations per microplate. After the exposure the apoptosis assay was performed following the manufacturers manual. In brief, the microplates were removed from the incubator following $24 \mathrm{~h} \mathrm{Ag}$ nanoparticle exposure and were allowed to cool to room temperature. The luminometer was programmed to take a $1 \mathrm{~s}$ integrated reading. Then $100 \mu \mathrm{l} /$ well of nucleotide releasing reagent (NRR) was added and kept for at least $5 \mathrm{~min}$. After that, $20 \mu \mathrm{l} /$ well of NMR was added and a $1 \mathrm{~s}$ integrated reading (Reading A) was taken in luminometeric plate reader. The plates were then kept for $10 \mathrm{~min}$ and $1 \mathrm{~s}$ integrated reading (Reading B) was taken. Then finally $20 \mu \mathrm{l} /$ well of ADP-CR was added and again held for $5 \mathrm{~min}$ and finally $1 \mathrm{~s}$ integrated reading (Reading $\mathrm{C}$ ) was taken. Finally the ADP:ATP ratio was calculated from the readings using the following formula (Reading C - Reading B)/Reading A.

This assay is based upon the bioluminescent measurement of ATP that is present in all metabolically active cells. The bioluminescent method uses luciferase, which generates light from ATP and luciferin according to the following reaction:

$\mathrm{ATP}+$ Luciferin $\stackrel{\text { Luciferase }}{\underset{\mathrm{Mg}_{++}}{\longrightarrow}}$ Oxyluciferin $+\mathrm{AMP}+\mathrm{PPi}+\mathrm{CO}_{2}$

(Lonza Rockland, Inc., www.lonza.com.biotechserv@lonza.com).

The emitted light intensity is linearly related to the ATP concentration and is measured using a luminometer. The assay is conducted at ambient temperature $\left(18-22^{\circ} \mathrm{C}\right)$, the optimal temperature for luciferase. This kit measures the intracellular AD$P: A T P$ ratio which can be used to distinguish between the different modes of cell death, whether the cell dies via apoptosis or necrosis.

\subsection{Statistical analysis}

At least three independent experiments were conducted for each toxicity endpoint. Test results for each assay were expressed as percentage of the unexposed control \pm standard deviation (SD). Control values were set as $100 \%$. Differences between samples and the control were evaluated using the statistical analysis package SPSS 14.0. Statistically significant differences were set at $p<0.01$. Normality of data was confirmed with $\mathrm{Q}-\mathrm{Q}$ percentile plots and Kolmogorov-Smirnov tests. Equality of variances was evaluated using Levène tests. One-way analysis of variances (ANOVA) followed by Dunnett's multiple comparison tests were carried out for normally distributed samples with homogeneous variances. Cytotoxicity data was fitted to a sigmoidal curve and a four parameter non-linear logistic model used to calculate the Lethal Dose of nanomaterial that caused a $50 \%$ inhibition in comparison to untreated controls $\left(\mathrm{LD}_{50}\right)$. All $\mathrm{LD}_{50}$ values were calculated using the average cytotoxicity data of the three independent experimental results and their associated errors. $\mathrm{LD}_{50}$ values are reported $\pm 95 \%$ confidence intervals $( \pm 95 \% \mathrm{CI})$. Lethal dose $50\left(\mathrm{LD}_{50}\right)$ values were estimated using Xlfit $3^{\mathrm{TM}}$, a curve fitting add-on for Microsoft ${ }^{\circledR}$ Excel (ID Business Solutions, UK).

\section{Results}

\subsection{Particle characterization}

The particle size of the Ag nanoparticles was evaluated using a variety of methods namely DLS, TEM and SEM. DLS study have shown average number size-distribution peak-sizes of $100 \mathrm{mg} / \mathrm{l}$ $\mathrm{Ag}$ nanoparticles in $\mathrm{dH}_{2} \mathrm{O}$, HeLa media and in $\mathrm{HaCaT}$ media as 28.41, 65.45 and $68.55 \mathrm{~nm}$, respectively (Fig. 1a). Size distribution plots of $\mathrm{Ag}$ nanoparticles in $\mathrm{dH}_{2} \mathrm{O}$ and $\mathrm{HaCaT}$ media are also shown as an example in Fig. 1b and Fig. 1c, respectively. The sizes of the $\mathrm{Ag}$ nanoparticles were calculated from the highest peak value of size/number in DTS Nano software. The variation in size can be attributed to changes in the hydrodynamic radius of the particle in the different media due to particle and media interactions, where steric stabilization in the media was observed for the $\mathrm{Ag}$ nanoparticles of 65-69 $\mathrm{nm}$ size-range and the larger particles of around $500 \mathrm{~nm}$ size-range, as observed in Fig. 1c, were may be due to particle agglomeration upon dispersion in the media. In fact DLS measures the hydrodynamic radius and not the physical particle size. The average diameter yielded from the TEM study was $29.57 \mathrm{~nm}$ (Fig. 1d) and SEM analysis was $<50 \mathrm{~nm}$ (Fig. 1e). Both of which reflect more accurately the physical particle diameter. These combined studies confirmed the test particles had an average diameter in $\mathrm{dH}_{2} \mathrm{O}$ of approximately $27 \mathrm{~nm}$. The DLS size measurements of HaCaT and HeLa media was also performed as control and were found to be 8.14 and $9.24 \mathrm{~nm}$, respectively (Fig. 1a). BET analysis was performed to estimate the surface area of the $\mathrm{Ag}$ nanoparticles and was found to be $2.3 \pm 0.1 \mathrm{~m}^{2} / \mathrm{g}$.

The average zeta potential measured of $100 \mathrm{mg} / \mathrm{l} \mathrm{Ag}$ nanoparticles in $\mathrm{dH}_{2} \mathrm{O}$, HeLa media and in HaCaT media were -33.33, -20.67 and $-15.83 \mathrm{mV}$ (Fig. 1f). Zeta potential values of this nature would suggest that upon dispersion with the bath sonicator the particles form an unstable dispersion and would precipitate out with time. The average zeta potential of HaCaT and HeLa media without $\mathrm{Ag}$ nanoparticle were found to be 6.61 and $-6.22 \mathrm{mV}$ (Fig. 1d).

\subsection{Standard cytotoxicity assays}

For all assays, i.e., AB, NR, Coomassie Blue and MTT, a dose dependent response was observed and an $\mathrm{LD}_{50}$ values were calculated. Cytotoxicity data for the $\mathrm{Ag}$ nanoparticles and the HaCaT and HeLa cells are presented in Table 1 and Figs. 2-5.

The $\mathrm{LD}_{50}$ values presented in table suggest that MTT assay was the most sensitive assay among the four assays in both the cell lines. Coomassie Blue assay was found to be least sensitive in HaCaT cells, while in HeLa cells Neutral Red assay was found to be least sensitive. Viability was found to be decreasing with the increasing exposure time in $A B, N R, C B$, MTT assay in both the cell lines.

$\mathrm{LD}_{50}$ values of HeLa cells are much lower than HaCaT cells at all exposure time points in Coomassie Blue and Neutral Red assay. In Alamar Blue and MTT assay the $\mathrm{LD}_{50}$ values of HeLa cells was slightly higher as compared to HaCaT cells after $24 \mathrm{~h}$ of exposure, but then again get lowered after 48 and $72 \mathrm{~h}$ exposure time.

The clonogenic assays showed decreasing colony numbers with the increasing concentration of Ag nanoparticles (Fig. 6). In the clonogenic assay the average plating efficiencies for the HaCaT and HeLa cells were $37 \%$ and $48 \%$, respectively. The $\mathrm{LD}_{50}$ values calculated from the clonogenic assay were $7.74 \mathrm{mg} / \mathrm{l}$ (confidence interval \pm 2.97 ) for the HaCaT cell line and $1.16 \mathrm{mg} / \mathrm{l}$ (confidence interval \pm 1.09 ) for that of the HeLa cells. At 2.5 and $5 \mathrm{mg} / \mathrm{l} \mathrm{Ag}$ nanoparticle concentrations the percentage of colonies formed in HeLa cells were $13.96 \%$ and $0 \%$, respectively. While in HaCaT cells at $2.5 \mathrm{mg} / \mathrm{l}$ and $5 \mathrm{mg} / \mathrm{l} \mathrm{Ag}$ nanoparticle concentration there was $83.16 \%$ and $62.5 \%$ respective colonies were observed, the colonies 

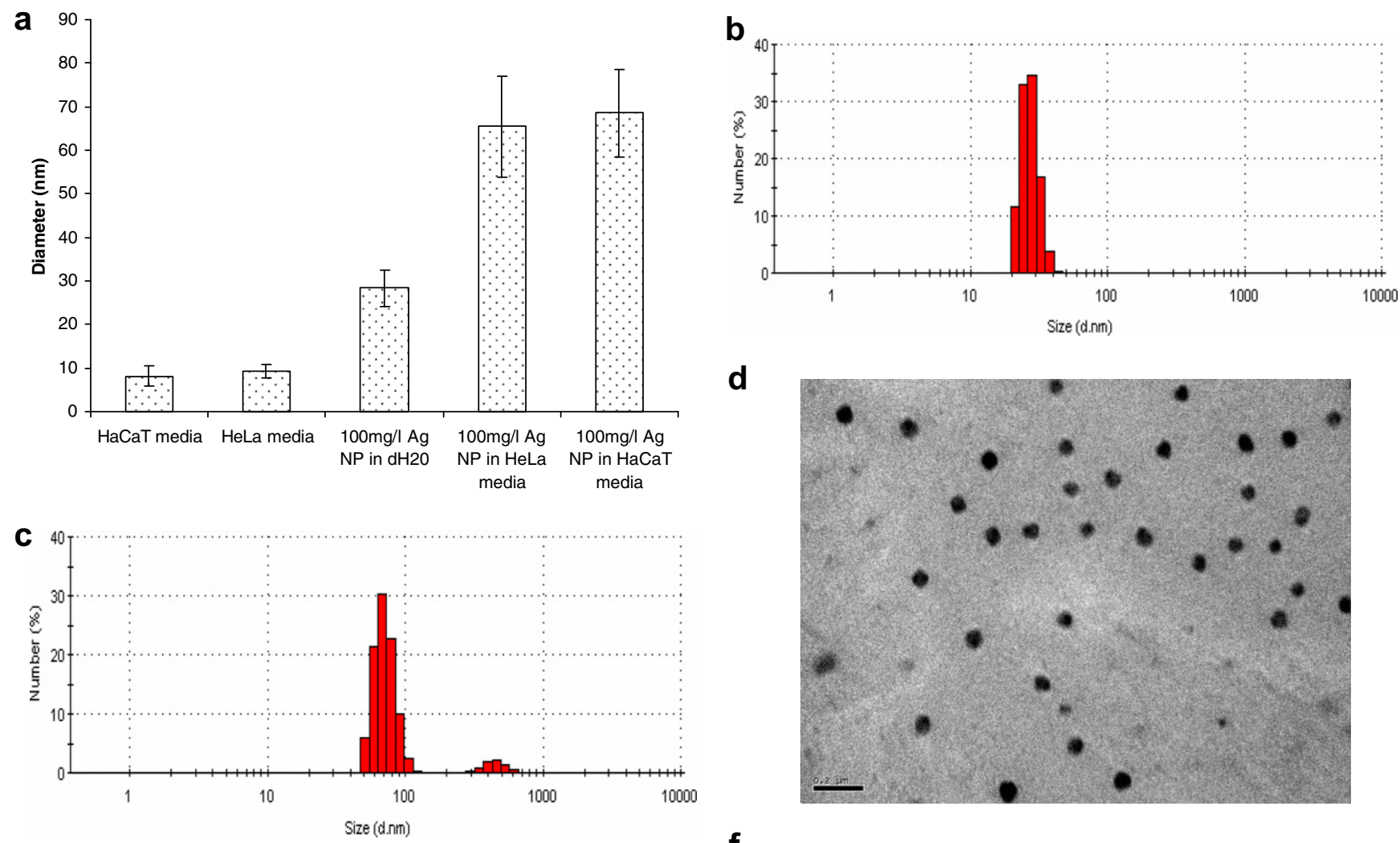

d

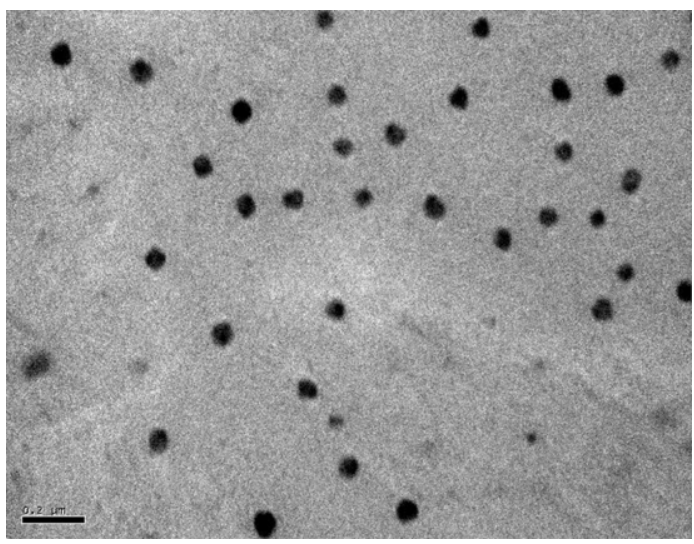

e

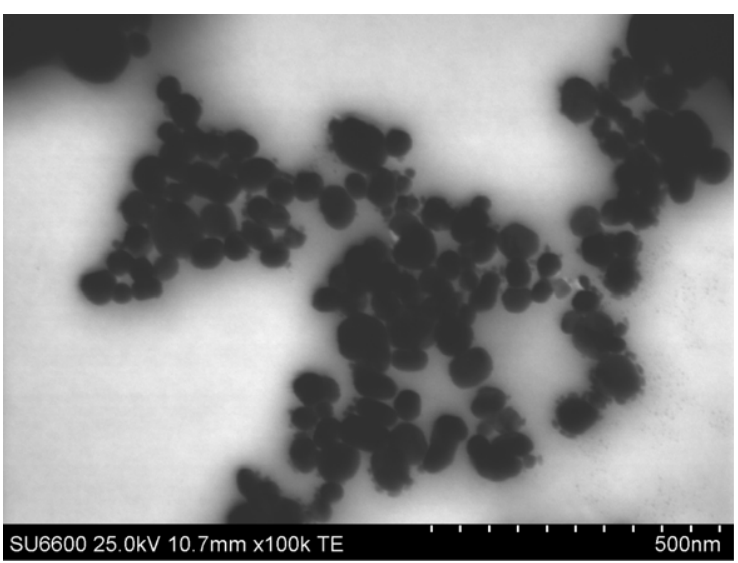

f

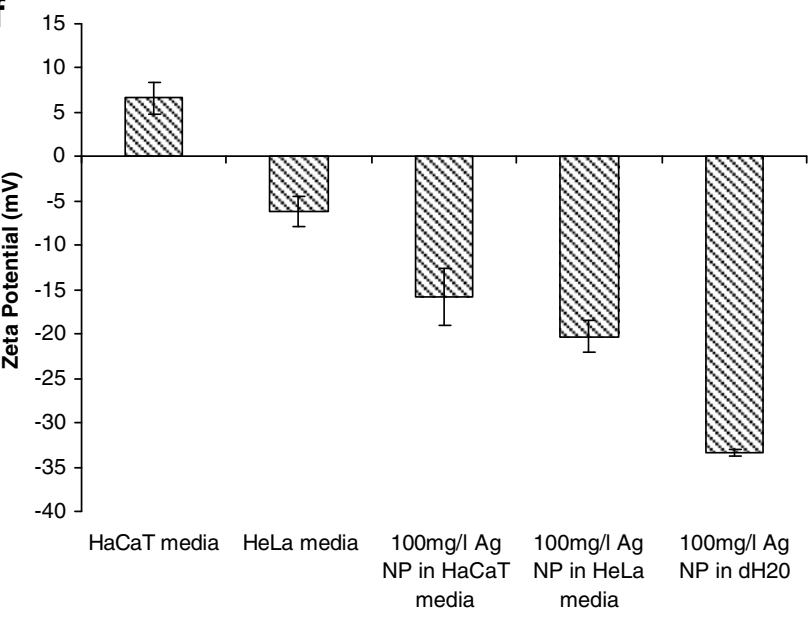

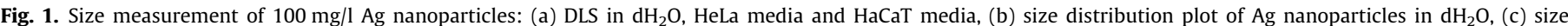

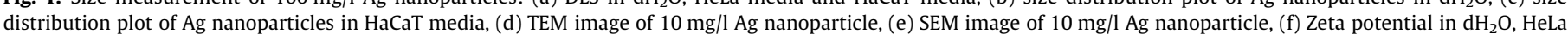
media and HaCaT media.

formed in HaCaT cells are much higher in percent than HeLa cells at same concentration. This shows that the proliferative capacity to form colonies of HaCaT cells in comparison to HeLa cells on exposure of $\mathrm{Ag}$ nanoparticles is much higher.

\subsection{Optical microscopic study}

Optical microscopic study have shown, with the increasing concentration of Ag nanoparticles the HaCaT (Fig. 7) and HeLa (Fig. 8) cells were looking unhealthy and the cells were dying out of the population. The population of HeLa cells were found to me more reduced at $200 \mathrm{mg} / \mathrm{l} \mathrm{Ag}$ nanoparticle exposure for $24 \mathrm{~h}$ in comparison to HaCaT cells.

\subsection{Reactive oxygen species study}

The ROS study has shown that in HaCaT cells with the increasing time of $\mathrm{Ag}$ nanoparticles exposure more ROS was produced at their respective concentration (Fig. 9a). In HeLa cells, similarly the amount of ROS was found to be increasing with the increasing time of exposure at their respective concentrations (Fig. 9b). In HeLa cells the maximum amount of ROS was produced at $20 \mathrm{mg} /$ 1 concentration after $5 \mathrm{~h}$ exposure of Ag nanoparticles, while in HaCaT cells maximum ROS production was observed at $31.25 \mathrm{mg} / \mathrm{l}$ concentration after $5 \mathrm{~h}$ exposure (Fig. 9). This study also shows that there was more ROS production in HeLa cells as compared to HaCaT cells. 
Table 1

Calculated $\mathrm{LD}_{50}(\mathrm{mg} / \mathrm{l})$ values resulting to exposure to $\mathrm{Ag}$ nanoparticles for the $\mathrm{AB}, \mathrm{NR}, \mathrm{CB}$ and MTT assays in the HaCaT and HeLa cell lines.

\begin{tabular}{|c|c|c|c|c|c|c|c|c|c|c|c|c|}
\hline \multirow[t]{2}{*}{$\begin{array}{l}\text { Cell } \\
\text { lines }\end{array}$} & \multicolumn{3}{|c|}{$\begin{array}{l}\mathrm{CB} \text { assay } \mathrm{LD}_{50}(\mathrm{mg} / \mathrm{l}) \text { (confidence } \\
\text { interval) }\end{array}$} & \multicolumn{3}{|c|}{$\begin{array}{l}\text { NR assay } \mathrm{LD}_{50}(\mathrm{mg} / \mathrm{l}) \text { (confidence } \\
\text { interval) }\end{array}$} & \multicolumn{3}{|c|}{$\begin{array}{l}\text { AB assay } \mathrm{LD}_{50}(\mathrm{mg} / \mathrm{l}) \text { (confidence } \\
\text { interval) }\end{array}$} & \multicolumn{3}{|c|}{$\begin{array}{l}\text { MTT assay } \mathrm{LD}_{50}(\mathrm{mg} / \mathrm{l}) \text { (confidence } \\
\text { interval) }\end{array}$} \\
\hline & $24 \mathrm{~h}$ & $48 \mathrm{~h}$ & $72 \mathrm{~h}$ & $24 \mathrm{~h}$ & $48 \mathrm{~h}$ & $72 \mathrm{~h}$ & $24 \mathrm{~h}$ & $48 \mathrm{~h}$ & $72 \mathrm{~h}$ & $24 \mathrm{~h}$ & $48 \mathrm{~h}$ & $72 \mathrm{~h}$ \\
\hline $\mathrm{HaCaT}$ & $\begin{array}{l}181 \\
( \pm 30.92)\end{array}$ & $\begin{array}{l}140.5 \\
( \pm 26.37)\end{array}$ & $\begin{array}{l}106.4 \\
( \pm 11.56)\end{array}$ & $\begin{array}{l}192.5 \\
( \pm 58.55)\end{array}$ & $\begin{array}{l}116 \\
( \pm 32.99)\end{array}$ & $\begin{array}{l}65.3 \\
( \pm 19.34)\end{array}$ & $\begin{array}{l}80.6 \\
( \pm 22.13)\end{array}$ & $\begin{array}{l}35.2 \\
( \pm 5.37)\end{array}$ & $\begin{array}{l}29 \\
( \pm 2.99)\end{array}$ & $\begin{array}{l}51.8 \\
( \pm 19.14)\end{array}$ & $\begin{array}{l}35.6 \\
( \pm 6.79)\end{array}$ & $\begin{array}{l}30.4 \\
( \pm 8.64)\end{array}$ \\
\hline HeLa & $\begin{array}{l}88.6 \\
( \pm 24.06)\end{array}$ & $1.7( \pm 3.87)$ & $2.1( \pm 0.91)$ & $\begin{array}{l}180.6 \\
( \pm 28.12)\end{array}$ & $\begin{array}{l}18.4 \\
( \pm 8.62)\end{array}$ & $12.7( \pm 6.4)$ & $\begin{array}{l}80.9 \\
( \pm 29.54)\end{array}$ & $\begin{array}{l}14.3 \\
( \pm 1.14)\end{array}$ & $\begin{array}{l}6.9 \\
( \pm 2.76)\end{array}$ & $\begin{array}{l}56.4 \\
( \pm 13.93)\end{array}$ & $\begin{array}{l}0.09 \\
( \pm 0.15)\end{array}$ & $\begin{array}{l}0.04 \\
( \pm 0.18)\end{array}$ \\
\hline
\end{tabular}
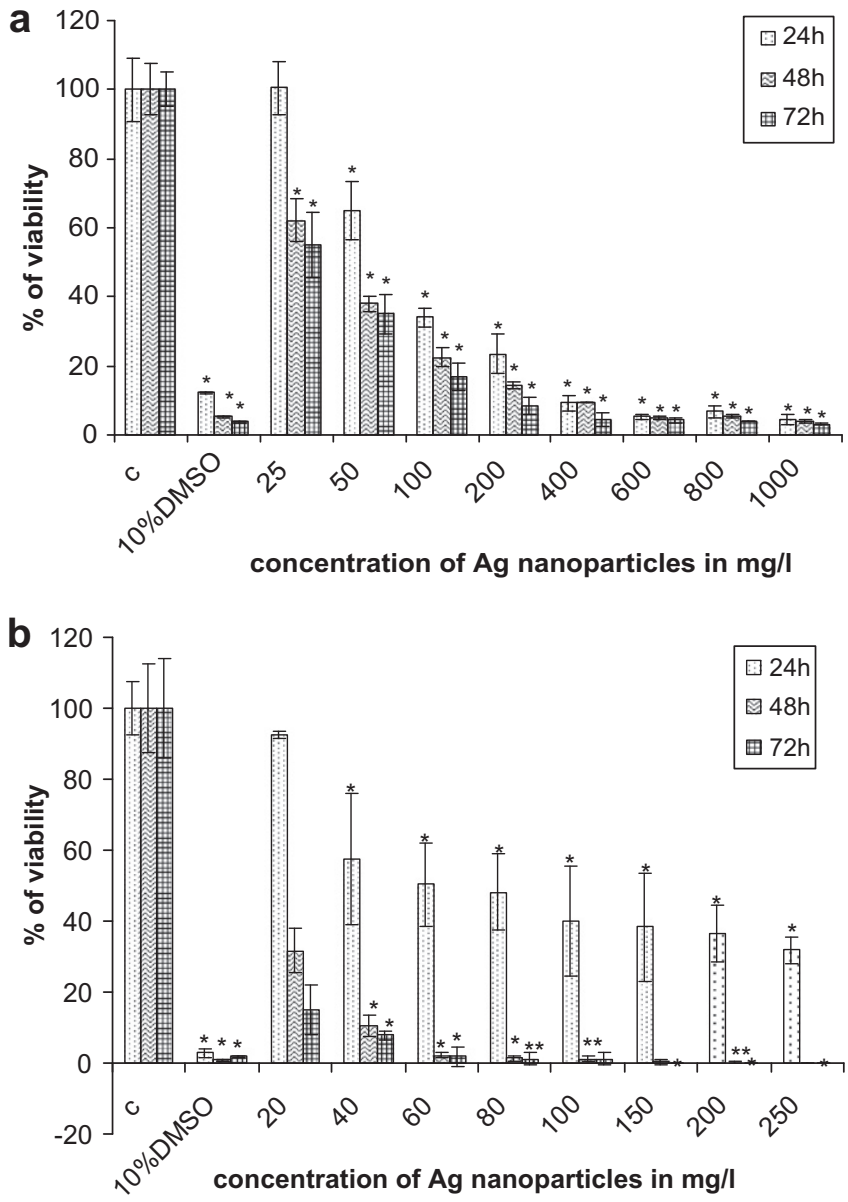

Fig. 2. Cytotoxicity of Ag nanoparticles after 24, 48, and 72 h exposures determined by the Alamar Blue assay - (a) in HaCaT cells, (b) in HeLa cells. Data are expressed as percent of control mean \pm SD of three independent experiments. Data are expressed as percent of control mean $\pm \mathrm{SD}$ of three independent experiments. ${ }^{*}$ denotes a statistically significant $(p<0.01)$ difference from the unexposed control.

\subsection{Intracellular GSH study}

The intracellular GSH measurement study have shown decrease in the intracellular GSH level with the increasing concentration of Ag nanoparticle in both HaCaT and HeLa cell lines after $24 \mathrm{~h}$ exposure (Fig. 10). The rate of intracellular GSH level depletion is much higher in HeLa cells in compare to HaCaT cells. $100 \mathrm{mg} / \mathrm{l} \mathrm{Ag}$ nanoparticle exposures to HaCaT and HeLa cells for 24 h have shown 5.3\% and 59.57\% respective GSH depletion (Fig. 10).

\subsection{Adenylate kinase release study}

The adenylate kinase release study have shown that with the increasing concentration of $\mathrm{Ag}$ nanoparticles, the percentage of adenylate kinase release in HaCaT (Fig. 11a) and HeLa (Fig. 11b)
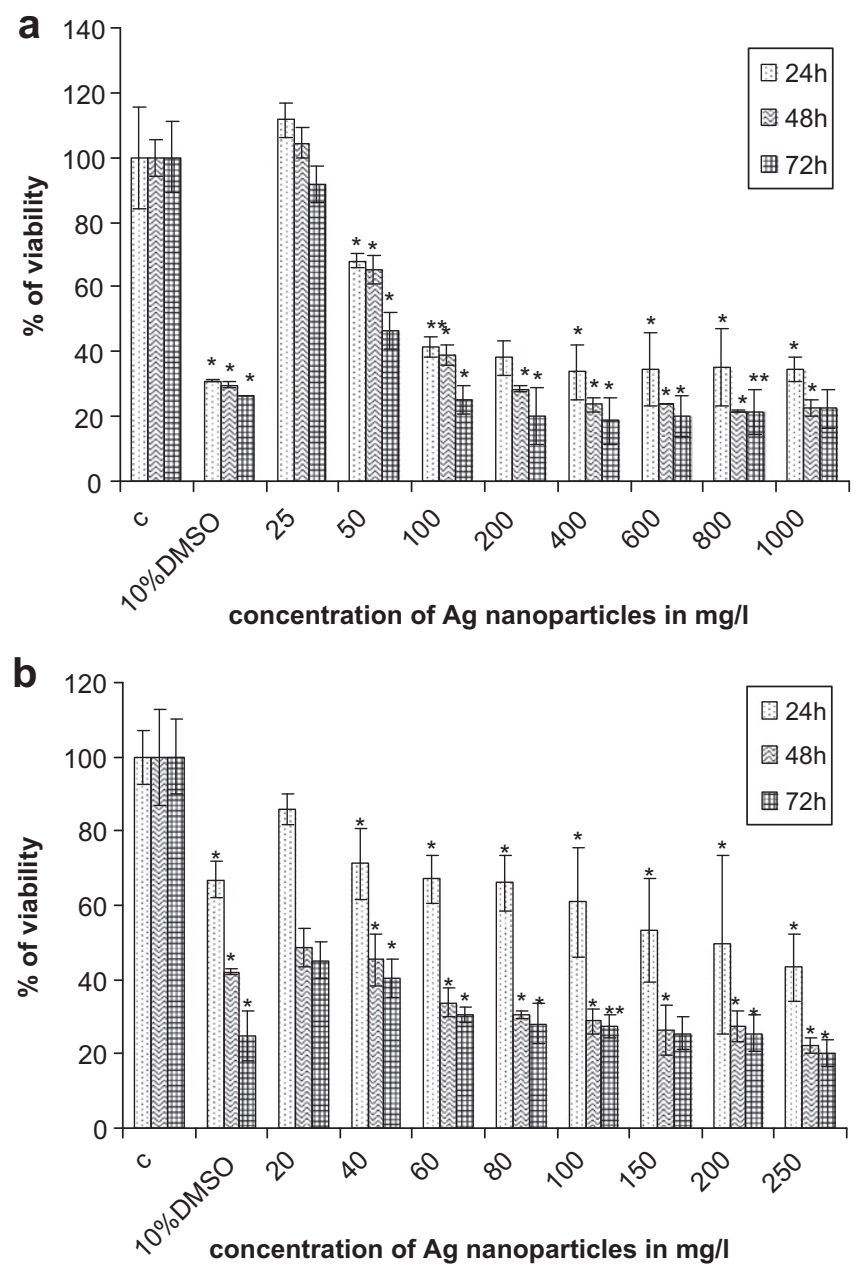

Fig. 3. Cytotoxicity of Ag nanoparticles after 24, 48, and 72 h exposures determined by the Neutral Red assay - (a) in HaCaT cells, (b) in HeLa cells. Data are expressed as percent of control mean $\pm S D$ of three independent experiments. ${ }^{*}$ denotes a statistically significant $(p<0.01)$ difference from the unexposed control.

cells were increased as compare to the controls. With the increasing hours of exposure, the adenylate kinase release from both the cell lines further increases (Fig. 11a and b). Upon $100 \mathrm{mg} / \mathrm{l} \mathrm{Ag}$ nanoparticle exposure for 24,48 and $72 \mathrm{~h}$ the percentage of AK release as compare to the controls from the HaCaT cells were $133.19 \%$, $164.41 \%$ and $233.62 \%$, respectively, while in HeLa cells the percentage of AK release at same concentration and exposure time points was found to be $156.5 \%, 195.33 \%$ and $226.48 \%$, respectively. Therefore, more AK was released from HeLa cells as compared to HaCaT cell. The huge difference in AK activity was observed at the highest concentration in both the cell lines, in HeLa cells the percentage of AK activity was $373.89 \%$ at $150 \mathrm{mg} / \mathrm{l}$ while in $\mathrm{HaCaT}$ cells it was $384.14 \%$ at $800 \mathrm{mg} / \mathrm{l}$ after $72 \mathrm{~h}$ of $\mathrm{Ag}$ nanoparticle exposure. This shows that there was much more loss of cell integrity, through 

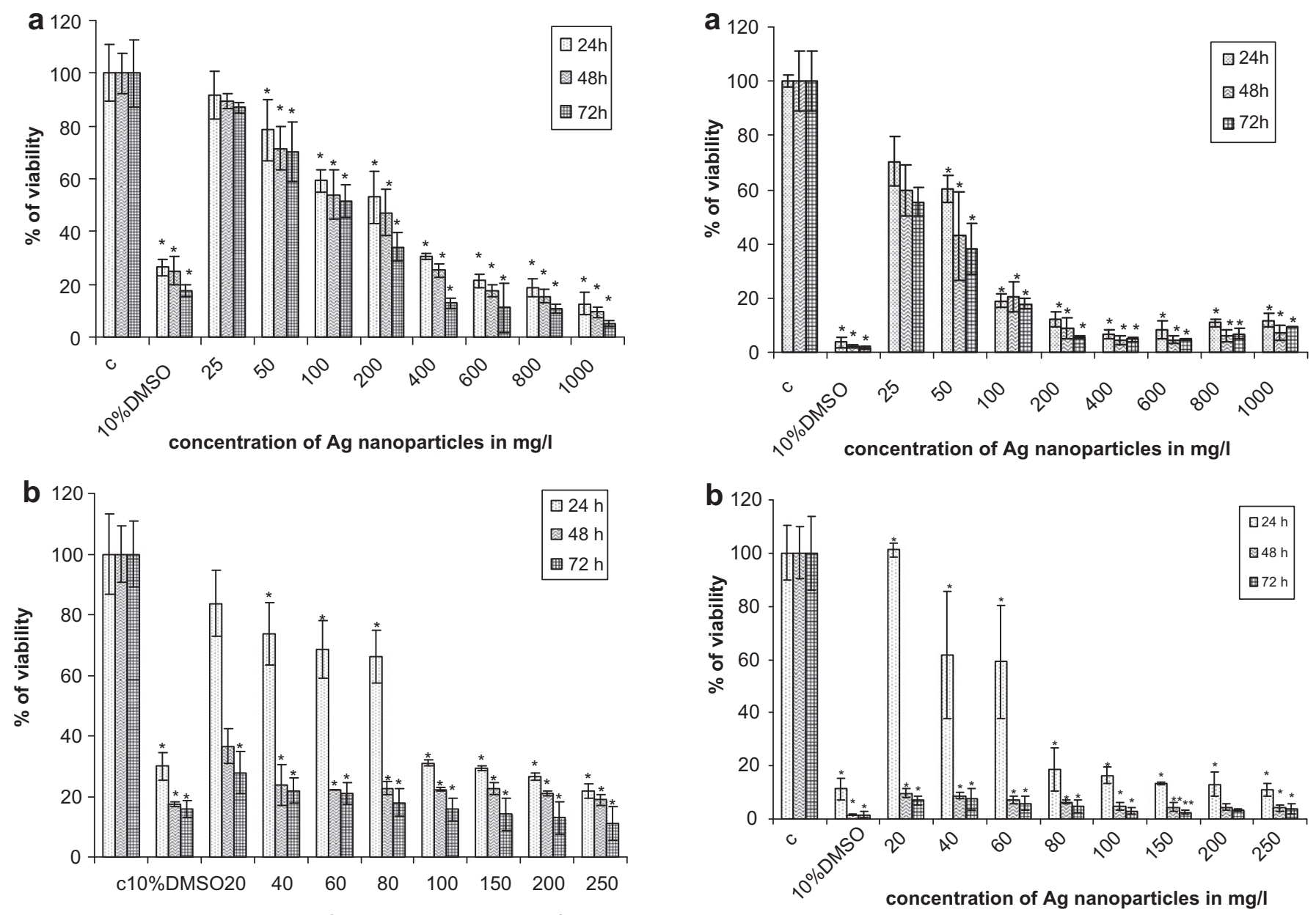

Fig. 5. Cytotoxicity of Ag nanoparticles after 24, 48, and $72 \mathrm{~h}$ exposures determined by the MTT assay - (a) in HaCaT cells, (b) in HeLa cells. Data are expressed as percent of control mean \pm SD of three independent experiments. Data are expressed as percent of control mean $\pm S D$ of three independent experiments. ${ }^{*}$ denotes a statistically significant $(p<0.01)$ difference from the unexposed control. (a) in HaCaT cells, (b) in HeLa cells. Data expressed as percent of control mean \pm SD of three independent experiments. Data are expressed as percent of control mean \pm SD of three independent experiments. * denotes a statistically significant $(p<0.01)$ difference from the unexposed control.

the damage of plasma memberane was occurred of HeLa cells as compared to HaCaT cells upon $\mathrm{Ag}$ nanoparticle exposure.

\subsection{Apoptosis study}

The apoptosis study was shown an increase in the ADP:ATP ratios over control ratios, which shows cells has entered apoptotic pathway. In HaCaT and HeLa cell lines with increasing concentration of Ag nanoparticles there was a significant increase in apoptotic cell population (Fig. 12). When both the cell lines were compared it was found HeLa cells are undergoing more apoptotic cell death than HaCaT cells at same concentration and exposure time. Upon $100 \mathrm{mg} / \mathrm{l}$ of Ag nanoparticle exposure for $24 \mathrm{~h}$, ATP:ADP ratio in HeLa was 0.31 while in HaCaT it was 0.22 . This shows a much lower level of ATP production in HeLa cells than HaCaT cells when compared to their respective controls upon exposure to the same concentration of Ag nanoparticle. The assay also displayed an increase in the intracellular ADP level in HeLa cells in comparison to the HaCaT cells, this resulted in an increase in the ADP:ATP ratios compared to their associated controls.

\section{Discussion}

Exposure of $\mathrm{Ag}$ nanoparticles to the body is becoming increasingly widespread and intimate. Consequently, there is an increased

potential for direct contact between $\mathrm{Ag}$ nanoparticles, biomolecules and cells in specific outer and inner organs. This study examines the effect of $\mathrm{Ag}$ nanoparticles on human dermal noncancerous (HaCaT) and cervical cancer (HeLa) cell lines. The toxicity of $\mathrm{Ag}$ nanoparticle is well known (AshaRani et al., 2009; Moaddab et al., 2011; Kim et al., 2009) but how cells of diverse origin react with the same Ag nanoparticle in different manner and the possible reason behind this difference has been illustrated in this paper.

The physio-chemical characteristics of nanoparticles play a significant role in their effect on biological systems (Oberdörster et al., 2000; Donaldson et al., 2004). The principal parameters of nanoparticles are their shape (including aspect ratios where appropriate), size, and the morphological sub-structure of the substance. The chemical composition and the intrinsic toxicological properties of the chemical are also of importance for toxicity of particles (Renwick et al., 2004). The zeta potential of the particle has been reported to play a significant role in its interaction with different biomolecules (Vila et al., 2002) and the change in the zeta potential in the exposure medium has been shown to correlate well with toxic response (Naha et al., 2009; Mukherjee et al., 2010a).

The size measurement of AgNP by DLS technique shows its diameter in $\mathrm{dH} 2 \mathrm{O}$ was $28.41 \mathrm{~nm}$, but after dispersing it in the cell culture media supplemented with 10\% FBS the diameter increases to $65.45 \mathrm{~nm}$ in HeLa media and $68.55 \mathrm{~nm}$ in HaCaT media (Fig. 1a, $\mathrm{b}$ and $\mathrm{c}$ ). That indicates the possible interaction of AgNP with the 


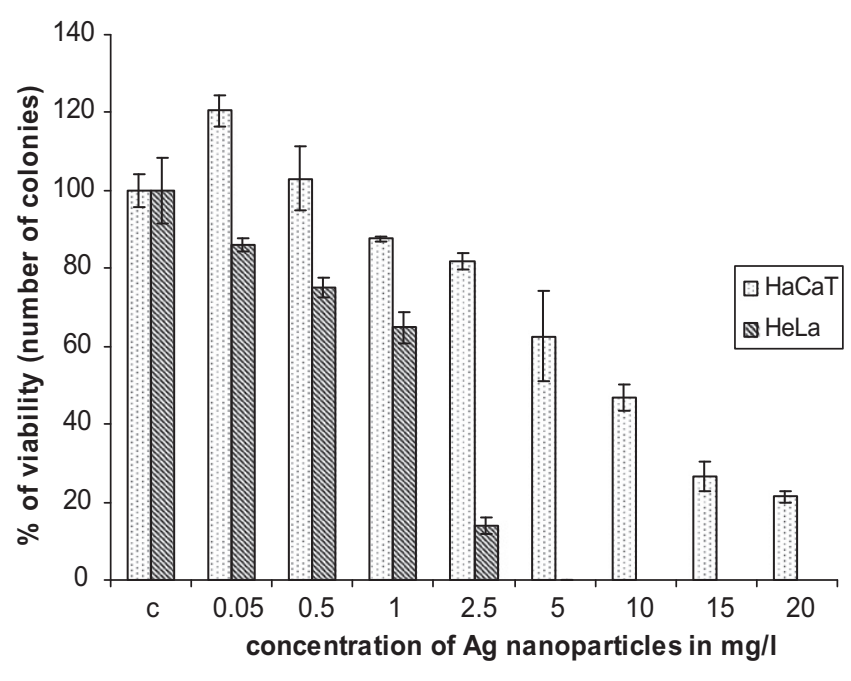

Fig. 6. Cytotoxicity of Ag nanoparticles after 8 days exposures determined by the Clonogenic assay in HaCaT cells and HeLa cells.

cell culture media components, which have been widely reported with different nanoparticles that leads to the formation of 'protein corona' (Lynch and Dawson, 2008; Lundqvist et al., 2008). The zeta potential study have also shown the decrease in the negative zeta potential of the AgNP upon its dispersion in the 10\% FBS supplemented cell culture media, where in $\mathrm{dH}_{2} \mathrm{O}$ it was $-33.33 \mathrm{mV}$ and in HeLa and HaCaT media it was -20.67 and $-15.83 \mathrm{mV}$, respectively (Fig. 1f). The zeta potential study further confirms the interaction of AgNP with the cell culture media components. Such an interaction of the nanoparticles with the components of the cell culture medium has been demonstrated to elicit a secondary or indirect toxic response in the case of single walled carbon nanotubes (Casey et al., 2007, 2008) and it is probable that there are similar contributions to the toxic response observed here. Therefore, in an independent experiment to investigate the cytotoxicity of Ag nanoparticle interacted media was performed. Where different concentrations of $\mathrm{Ag}$ nanoparticle were first prepared in the respective cell culture media and kept in $37^{\circ} \mathrm{C}$ incubator for $24 \mathrm{~h}$ and then following incubation $\mathrm{Ag}$ nanoparticles were removed from the media by centrifuging it at $14,000 \mathrm{rpm}$ for $20 \mathrm{~min}$. The supernatants were then collected and filtered using cellulose acetate $0.2 \mu \mathrm{m}$ syringe filters. Both the tested cell lines were then exposed to this supernatant for $24-72 \mathrm{~h}$ and cellular viability assessed using the $\mathrm{AB}$ assay. The toxicity found from supernatant media was not comparable in magnitude to the cytotoxicity observed from direct nanoparticle exposure and was only observed at the $72 \mathrm{~h}$ exposure time-point. Upon exposure of $100 \mathrm{mg} / \mathrm{l} \mathrm{Ag}$ nanoparticle supernatant in HeLa cells after $72 \mathrm{~h}$ exposure to the a

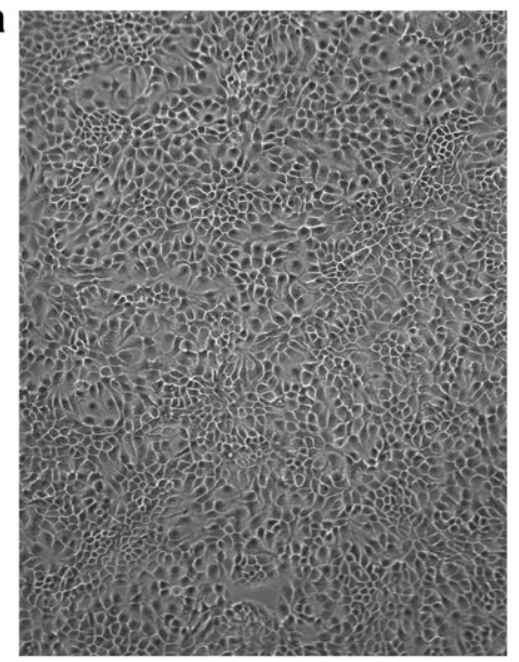

C

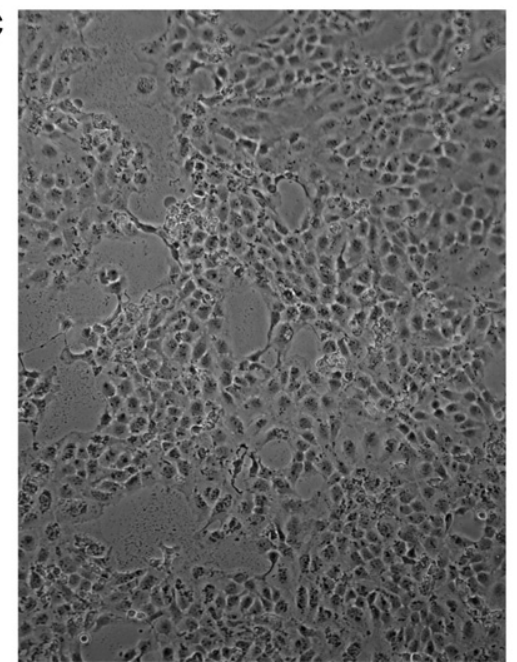

b

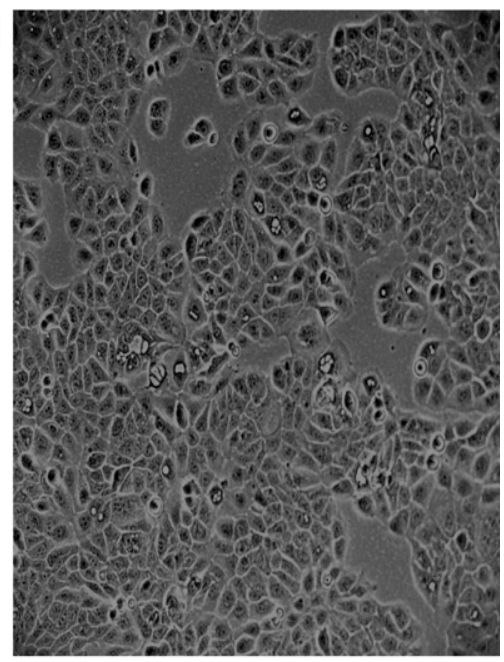

d

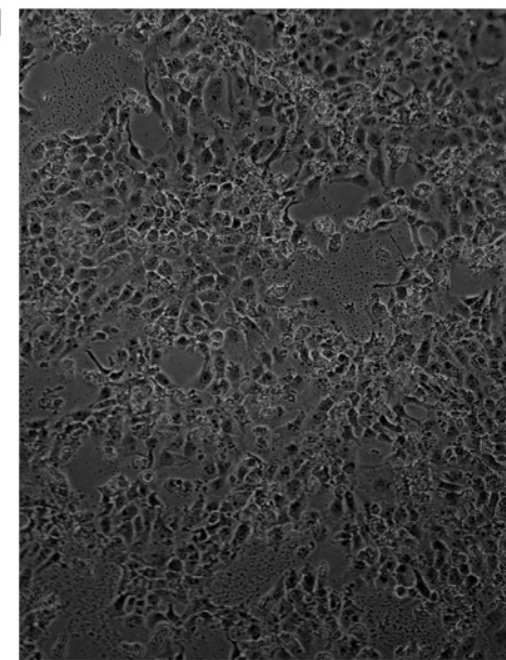

Fig. 7. Optical micrograph of HaCaT cells after $24 \mathrm{~h} \mathrm{Ag}$ nanoparticle exposure at (a) $0 \mathrm{mg} / \mathrm{l}$, (b) $50 \mathrm{mg} / \mathrm{l}$, (c) $100 \mathrm{mg} / \mathrm{l} \mathrm{and} \mathrm{(d)} 200 \mathrm{mg} / \mathrm{l}$. 

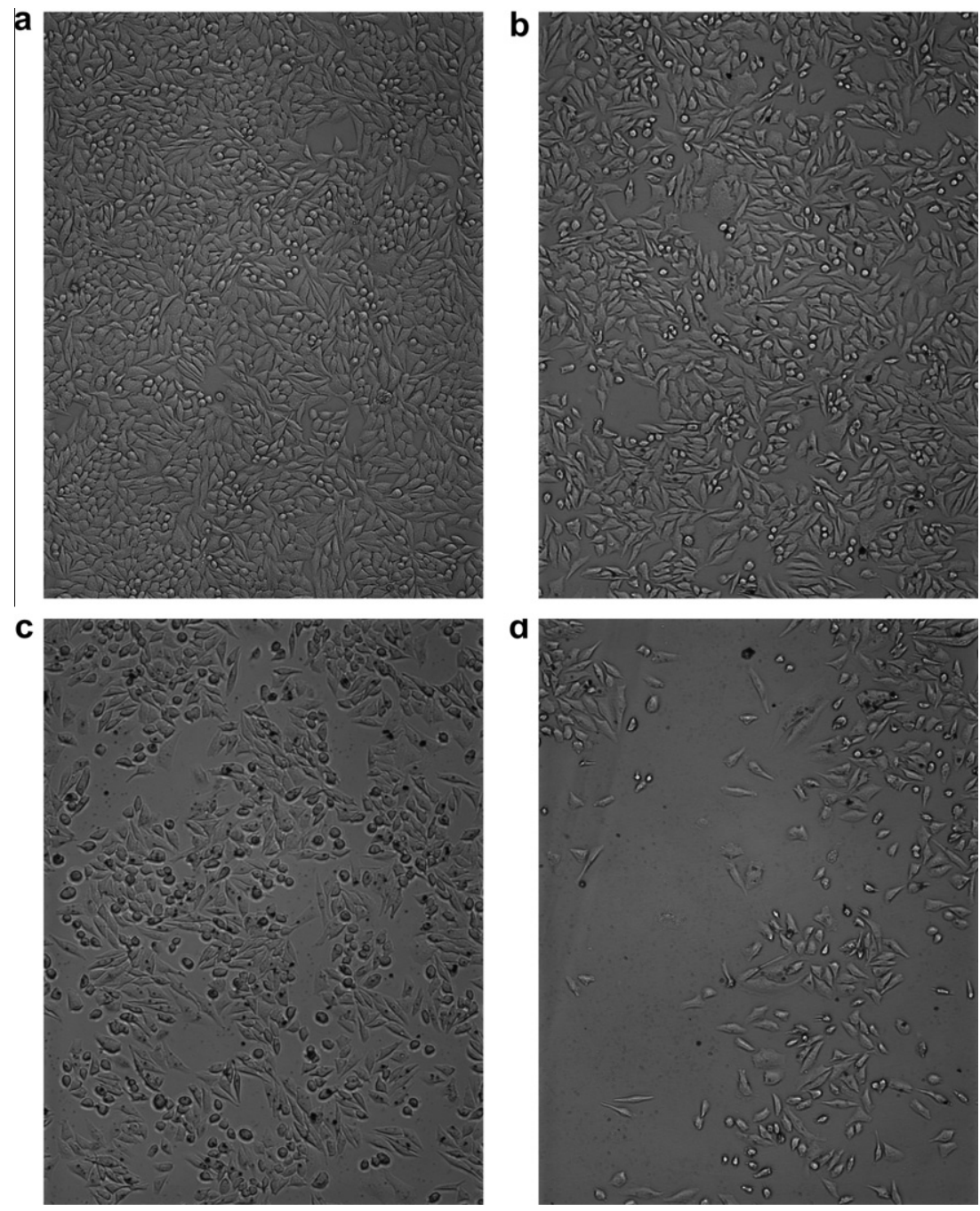

Fig. 8. Optical micrograph of HeLa cells after $24 \mathrm{~h} \mathrm{Ag} \mathrm{nanoparticle} \mathrm{exposure} \mathrm{at} \mathrm{(a)} 0 \mathrm{mg} / \mathrm{l}$, (b) $50 \mathrm{mg} / \mathrm{l}$, (c) $100 \mathrm{mg} / \mathrm{l}$ and (d) $200 \mathrm{mg} / \mathrm{l}$.

supernatant, the cell viability observed was $86.74 \%$, while no cytotoxicity was observed in HaCaT cells (data not shown). This data suggests that there is indeed a contribution of secondary cytotoxicity from the $\mathrm{Ag}$ nanoparticle and cell culture media interaction however the observed effects were only noted at longer exposure time-points.

Following physiochemical characterization a series of toxicological studies were performed using a battery of assays to assess the in vitro cytotoxic effects of $\mathrm{Ag}$ nanoparticle on these two cell lines of diverse tissues and to understand the difference in the response by the two cell lines.

In Table 1 dose response from $\mathrm{AB}$ assay shows that in HaCaT and HeLa cell lines the cytotoxic response was increasing with the increasing concentration and time points of exposure. This indicates particles have a toxic effect on the basic cellular metabolism and proliferation of the cells as there was a decrease in the reduction of the Alamar Blue dye from Resazurin to Resorufin as observed from this assay. This Redox reaction could not happen as cytosolic and mitochondrial oxidoreductase enzyme activities were decreased with the increase in Ag nanoparticle concentration and exposure time (Fig. 2). Upon $100 \mathrm{mg} / \mathrm{l} \mathrm{AgNP}$ exposure for $72 \mathrm{~h}$, the decrease in the $\mathrm{AB}$ dye reduction than the control in $\mathrm{HaCaT}$ and HeLa cells were $16.75 \%$ and $1.11 \%$, respectively. This further indicates the higher sensitivity of HeLa cells than HaCaT cells upon Ag nanoparticle exposure.
The dose response of $\mathrm{Ag}$ nanoparticles to HaCaT and HeLa cells in NR assay shows that with the increasing concentration and time of exposure of AgNPs, less NR dye was uptaken by the cellular lysosomes, which indicated the cellular viability was decreasing with the increasing concentration and time of exposure of AgNPs. In dead cells, NR can no longer retain in the cytoplasmic vacuoles and the plasma membrane does not act as a barrier to retain the NR within the cells. Fig. 3 has shown the decrease in NR dye uptake in HaCaT and HeLa cells were $25.38 \%$ and $27.42 \%$, respectively upon $100 \mathrm{mg} / \mathrm{l} \mathrm{Ag}$ nanoparticle exposure for $72 \mathrm{~h}$.

$\mathrm{CB}$ assay shows that with the increasing concentration and exposure time the $\mathrm{CB}$ dye binding was decreased in both $\mathrm{HaCaT}$ and HeLa cells (Fig. 4). That suggests the degradation of cellular protein or reduction of protein synthesis upon AgNP exposure (Clare and Cormack, 1996). The percentage of CB dye binding to the cells than control upon $100 \mathrm{mg} / \mathrm{l} \mathrm{AgNP}$ exposure for $72 \mathrm{~h}$ in HaCaT and HeLa cells were $51.34 \%$ and $15.75 \%$, respectively. In this assay again the HeLa cells were found to be more sensitive than HaCaT cells.

The MTT assay determines the ability of viable cell's mitochondria to reduce the soluble, yellow MTT into an insoluble, purple formazan. The reduction of MTT to formazan indicates the decrease in mitochondrial metabolism of the cells. Therefore, the absorbance of formazan formed, directly correlates to the number of cells whose mitochondrial metabolism is intact even after the 


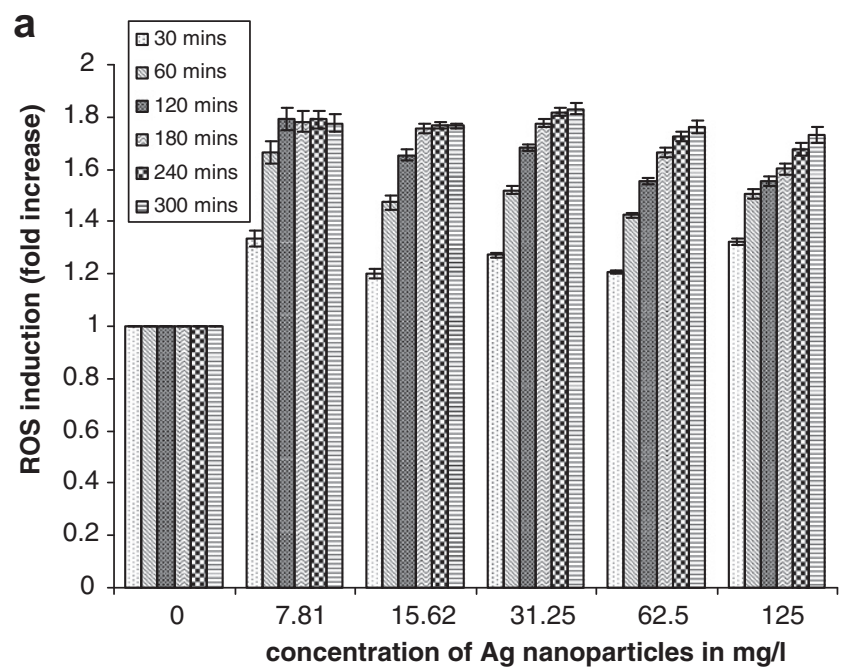

b

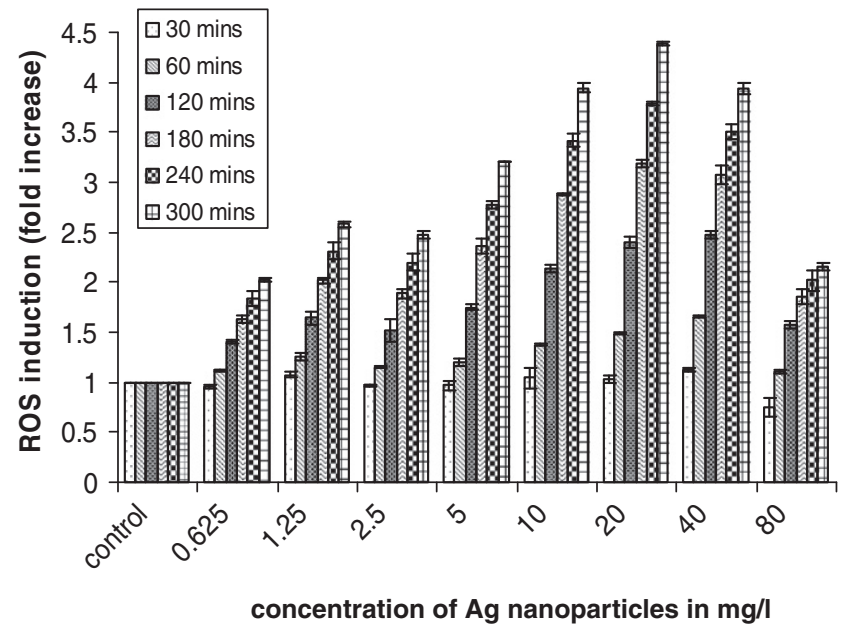

Fig. 9. ROS generation after different time points of Ag nanoparticle exposure in (a) HaCaT cells, (b) HeLa cells.

exposure of Ag nanoparticles. Dose response of AgNP in HaCaT and HeLa cells shows the decrease in the reduction of MTT to formazan with the increasing concentration and time of exposure. Upon $100 \mathrm{mg} / \mathrm{l} \mathrm{AgNP}$ exposure for $72 \mathrm{~h}$ in HaCaT and HeLa cells, the percentage of MTT conversion to formazan decreases to $17.71 \%$ and 3.07\%, respectively (Fig. 5). Therefore MTT assay also shows the higher sensitivity of HeLa cells to the Ag nanoparticles than HaCaT cells.

Clonogenic assay indicates the proliferative capacity of a single cell upon nanoparticle exposure for longer time period, which in this study was 8 days. Dose response from this assay shows the decrease in the colony number with the increasing concentration of AgNP in both the cell lines (Fig. 6). However, it also shows that the colony forming capacity in HeLa cells were much lesser than HaCaT cells upon AgNP exposure. Exposure of $2.5 \mathrm{mg} / \mathrm{l} \mathrm{AgNP}$ to HaCaT cells can form $83 \%$ colonies compare to the control, while HeLa cells can only form $14 \%$ colonies. This is also reflected in the $\mathrm{LD}_{50}$ values obtained from this study. The $\mathrm{LD}_{50}$ in HaCaT cells was $7.74 \mathrm{mg} / \mathrm{l}$, while that in HeLa cells was $1.16 \mathrm{mg} / \mathrm{l}$. Clonogenic assay therefore also suggest the higher sensitivity of HeLa cells when compare to HaCaT cells.

The responses from all the standard cytotoxicological assays ( $\mathrm{AB}, \mathrm{NR}, \mathrm{CB}, \mathrm{MTT}$ and Clonogenic assays) employed to test the Ag nanoparticle toxicity on the HaCaT and HeLa cells were found to

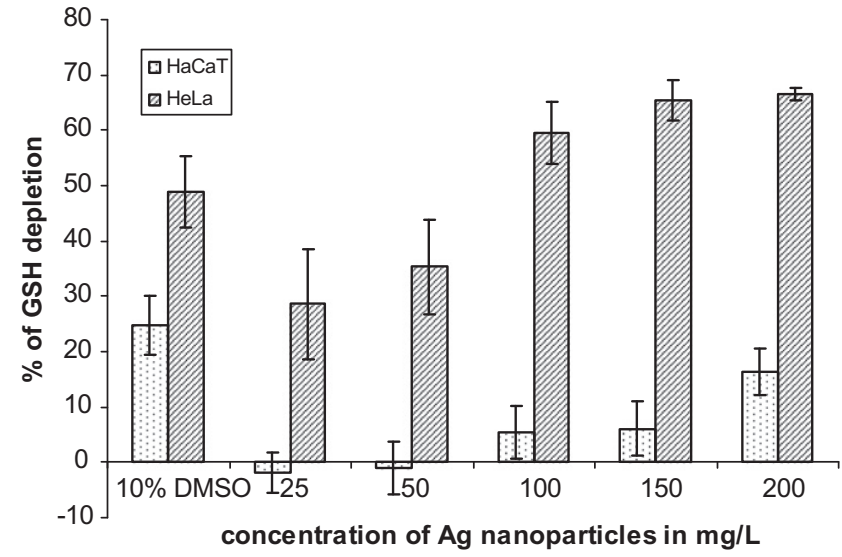

Fig. 10. Percentage of intracellular GSH depletion upon different concentrations of $\mathrm{Ag}$ nanoparticle exposures for $24 \mathrm{~h}$ to HaCaT and HeLa cells.
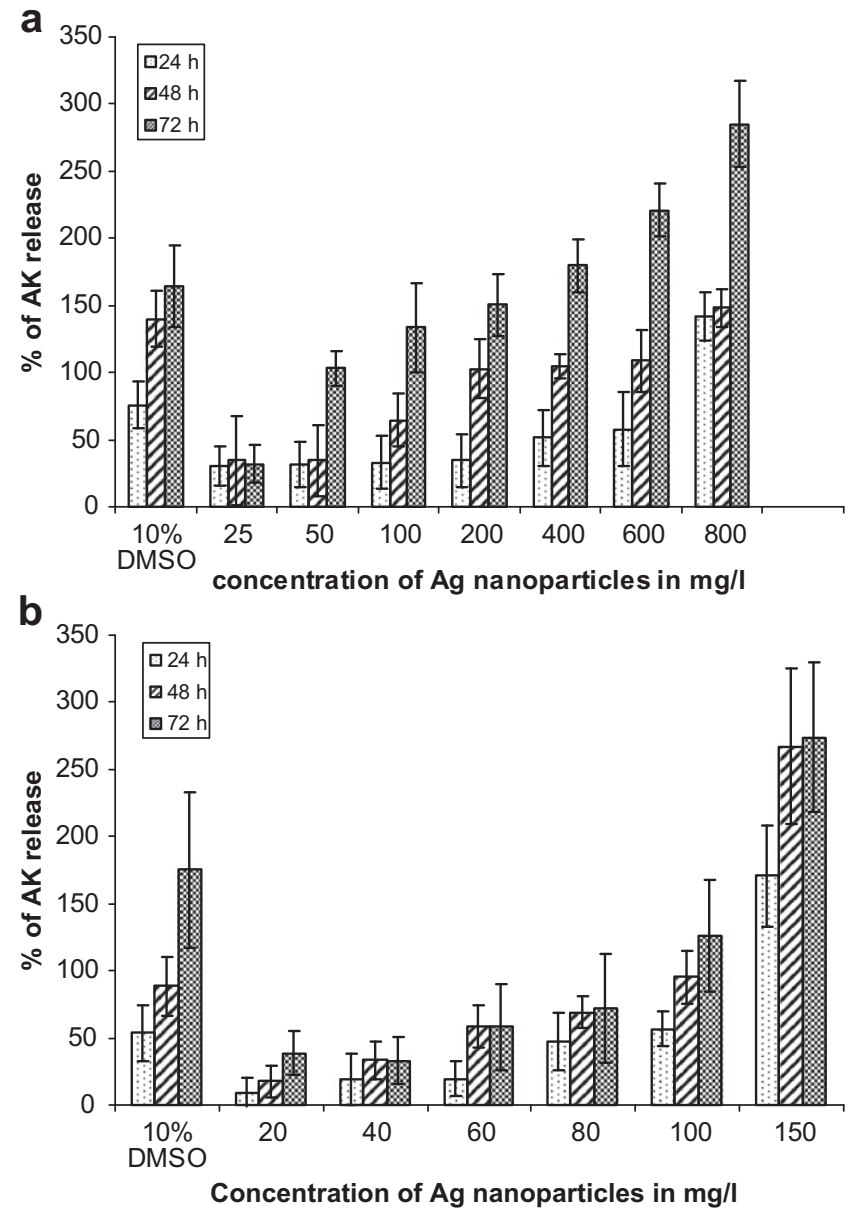

Fig. 11. Adenylate kinase release study upon Ag nanoparticle exposure in (a) HaCaT cells, (b) HeLa cells. Negative control is set to "zero".

be both dose and time dependant. In both cell lines the $\mathrm{LD}_{50}$ values were seen to decrease with increasing exposure time. In all cases the cytotoxic effect was noted to be greater in HeLa cells than in HaCaT cells. Among all the colorimetric based short term exposure (up to $72 \mathrm{~h}$ ) acute toxicity assays (i.e., AB, NR, CB and MTT assays) in both the cell lines, the MTT assay was noted to be the most sensitive as indicated by the lower $\mathrm{LD}_{50}$ values (Table 1 ) evaluated from this assay. The AB assay showed less sensitivity than MTT 


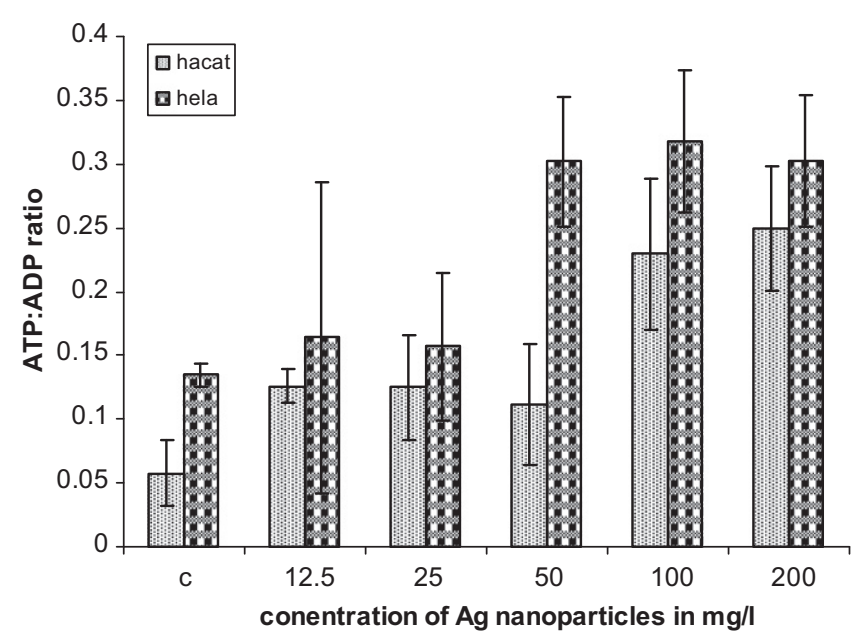

Fig. 12. Apoptosis induction in terms of increase in ADP:ATP ratio upon different concentrations of AgNP exposure in HaCaT and HeLa cells.

assay in both the cell lines. Whereas in the $72 \mathrm{~h}$ exposure study in $\mathrm{HaCaT}$ cells, NR assay was found to be less sensitive than AB assay, and $C B$ assay was found to be least sensitive among these four assays. The $72 \mathrm{~h}$ exposure study in HeLa cells showed CB assay as less sensitive than $A B$ assay and NR assay as the least sensitive among these four assays. The clonogenic assay yielded significantly lower $\mathrm{LD}_{50}$ values than that of the colorimetric endpoints, with the exception of the MTT assay in HeLa cell line. The particle exposure time in clonogenic assay is longer than other assays, i.e., 8 days, indicating chronic effects are more severe than acute effects. This assay verifies the findings of the colorimetric assays and also gives an indication that the presence of the $\mathrm{Ag}$ nanoparticle has an effect on the proliferative capacity of a single cell of the tested cell lines by the reduction in the number of colonies formed.

The dose responses from these assays suggest that upon $\mathrm{Ag}$ nanoparticle exposure the mitochondrial metabolism was most affected followed by the basic cellular metabolism and then the lysosomal activity and finally because of the toxic effect of these nanoparticles on the cells the cellular protein contents were also decreased. Among both the cell lines, HeLa cells were found to be more sensitive than HaCaT cells. One significant difference between the two cell lines is their natural antioxidant levels. The natural glutathione (GSH) level of $\mathrm{HaCaT}$ cell is $7300 \mathrm{nmol} / \mathrm{mg}$ protein (Snow et al., 2005) and HeLa cell is $\sim 220 \mathrm{nmol} / \mathrm{mg}$ protein (Tipnis et al., 1999). This huge difference in their natural GSH level could be an important reason for higher sensitivity of HeLa cells over HaCaT cells.

Following the standard cytotoxicity assays intracellular ROS generation was also monitored. In both cell lines a significant increase in the levels of ROS (Fig. 9) was observed in comparison to the unexposed controls. It was noted that the onset of oxidative stress in all the tested concentrations started typically within $30 \mathrm{~min}$ in both the cell lines. In HaCaT cell line a significant increase in ROS was noted in exposure concentrations well below the calculated $\mathrm{LD}_{50}$ values. A response of this nature would that at concentrations even were there was no observed cytotoxicity from the above standard cytotoxicity assays the presence of $\mathrm{Ag}$ nanoparticles can induce high levels of cellular oxidative stress. The amount of ROS generated upon AgNP exposure was higher in HeLa cells than in HaCaT cells (Fig. 9). The fold increase of ROS than control upon 10-20 mg/l AgNP exposure in HeLa cells were 3.934.39, whereas upon $15 \mathrm{mg} / \mathrm{l} \mathrm{AgNP}$ exposure that in HaCaT cells was 1.77. This could be due to the much lower natural GSH level in HeLa cells (Tipnis et al., 1999) than HaCaT cells (Snow et al., 2005) as GSH is an important antioxidant and ROS scavenger of the cell. Therefore an independent GSH study has shown that the rate of depletion of intracellular GSH level was much higher in HeLa cells when compared to that of HaCaT cells (Fig. 10). Such differences would account for the higher amount of ROS production observed in HeLa cells in comparison to HaCaT cells. ROS plays an important role in triggering many cellular pathways which can lead to cellular death, including cytokine activation (Brown et al., 2004) and caspase activation (Kim et al., 2009, Stennicke et al., 1998). They can also cause damage to the nuclear DNA by altering the chemical structure of the nucleotide bases and the deoxyribosyl backbone (Cooke et al., 2003, Valko et al., 2004). Therefore, intracellular ROS generation upon AgNP exposure is an important factor to its cytotoxicity.

ToxiLight ${ }^{\circledR}$ Assay assay quantifies the release of adenylate kinase from the cells which is an indication of the damage of the cell membrane. Once the plasma membrane has been damaged by cytotoxic action the AK will be available for detection in the surrounding medium. With the increasing Ag nanoparticle concentration in both the cell lines, an increasing release of adenylate kinase from the cells was observed which also increases with the exposure time (Fig. 11). This assay therefore suggests that with the increasing concentration and exposure time the Ag nanoparticle causes more damage to the cell membrane. Upon AgNP exposure more AK was found to be released from HeLa cells than HaCaT cells at lower dose (Fig. 11).

This damage in the cell membrane also indicates that more cell population is possibly dying by either necrotic or apoptotic pathway. This was confirmed when apoptosis study was performed by ApoGlow ${ }^{\circledR}$ Kit of Lonza Ltd (Wokingham, UK). ApoGlow ${ }^{\circledR}$ Kit helps in the differentiation of normal healthy proliferative cells, apoptotic cells and necrotic cells from the cellular ADP:ATP ratio. If a cell undergoes apoptosis, the test gives lower levels of ATP compare to controls, but show an increase in ADP, this eventually gives an increase in the ADP:ATP ratios over control ratios. In normal healthy cells the ADP:ATP ratio was observed below 0.11 , whereas in apoptotic cells the ratio was in between 0.11 and 1.0 and in cells undergoing necrosis by heat shock treatment the ADP:ATP ratio was observed in excess of 15.0 (Bradbury et al., 2000). The apoptosis study shows the ADP:ATP ratio in HaCaT and HeLa cells upon AgNP exposure were higher than that of the control and was within the range of apoptotic cell population (Fig. 12). The ADP:ATP ratio in HaCaT and HeLa cells upon $24 \mathrm{~h}$ $100 \mathrm{mg} / \mathrm{l} \mathrm{Ag}$ nanoparticle exposure were 0.22 and 0.31 , respectively. This indicates upon Ag nanoparticle exposure the cells were entering apoptosis and HeLa cells had more apoptotic cell population than HaCaT cells. This further indicates the higher sensitivity of HeLa cells than HaCaT cells.

Overall, the standard cytotoxicity assays shows more sensitivity of MTT assay upon short term exposure over other assays followed by $A B$ assay, $N R$ and $C B$ assays were the least sensitive ones. This further indicates upon $\mathrm{Ag}$ nanoparticle exposure mitochondria was getting affected first followed by basic cellular metabolism and lysosomal activity was decreasing later on. Optical microscopic study had also shown the cytotoxic effect of $\mathrm{Ag}$ nanoparticles on HaCaT (Fig. 7) and HeLa (Fig. 8) cells with their increasing concentration. Ag nanoparticles generate reactive oxygen species upon entering the cells and that creates oxidative stress to the cells. ROS plays an important role in the mitochondrial damage, therefore its generation upon AgNP exposure causing the higher mitochondrial toxicity. Ag nanoparticles also damage the cell membrane and therefore more AK release from the cells was observed upon increasing concentration and time of exposure of $\mathrm{Ag}$ nanoparticles. All these effects further activate the apoptotic pathways and therefore significant apoptotic cell populations were observed upon $24 \mathrm{~h} \mathrm{Ag}$ nanoparticle exposure and eventually cell dies. The interaction of AgNP with the media components, as indi- 
cated from the size and zeta potential measurements study, may also lead to secondary toxicity. The difference in the sensitivity of HaCaT and HeLa cells can be understood in terms of the difference in their natural antioxidant levels.

\section{Conclusions}

Size measurement study of $\mathrm{Ag}$ nanoparticles in the cell culture media showed the interaction of AgNP with the cell culture media components that suggest the significant protein adsorption by the nanoparticles in the cell growth media. This protein adsorption from the medium is also manifest in a dramatic change in the zeta potential and therefore surface properties of the particles. This could have possible effect on the toxic response of the Ag nanoparticles. HeLa cells were found to be more sensitive than HaCaT cells in all the assays and clonogenic assay showed the strongest response indicating potential chronic responses. All these different short term cytotoxicity assays show the effect of silver nanoparticles at different cellular level. Therefore proper interpretation of the dose response from these assays can help in the prediction of the mechanism of its cytotoxicity. ROS generation by Ag nanoparticles upon entering the cells is the key step which possibly initiates several pathways that leads to cell death. The difference in the sensitivity of different cell lines can be understood in terms of their natural antioxidant levels, which is a key behind their natural defence mechanism during oxidative stress. Therefore, this probably governs the sensitivity of the cell lines upon same nanoparticle exposure.

\section{Conflict of interest}

The author declares that there is no conflict of interest.

\section{Acknowledgements}

This project is funded under the Technological Sector Research Strand I, Post Graduate R\&D Skills Programme. This work was conducted under the framework of the INSPIRE programme, funded by the Irish Government's Programme for Research in Third Level Institutions, Cycle 4, National Development Plan 2007-2013, supported by the European Union Structural Fund. We would like to thank Sourav Prasanna Mukherjee for his help and support to carry out some of this work.

\section{References}

Ahn, M.H., Kang, C.M., Park, C.S., Park, S.J., Rhim, T., Yoon, P.O., Chang, H.S., Kim, S.H., Kyono, H., Kim, K.C., 2005. Titanium dioxide particle-induced goblet cell hyperplasia: association with mast cells and IL-13. Respir. Res. 13, 34.

AshaRani, P.V., Mun, G.L.K., Hande, M.P., Valiyaveettil, S., 2009. Cytotoxicity and genotoxicity of silver nanoparticles in human cells. ACS Nano 3, 279-290.

Boukamp, P., Petrussevska, R.T., Breitkreutz, D., Hornung, J., Markham, A., Fusenig, N.E., 1988. Normal human keratinization in a spontaneously immortalized aneuploid human keratinocyte cell line. J. Cell Biol. 106, 761-771.

Bradbury, D., Simmons, T., Slater, K., Crouch, S., 2000. Measurement of ADP:ATP ratio in human leukaemic cell lines can be used as an indicator of cell viability, necrosis and apoptosis. J. Immunol. Methods 243, 167-190.

Brown, D.M., Donaldson, K., Borm, P.J., Schins, R.P., Dehnhardt, M., Gilmour, P., Jimenez, L.A., Stone, V., 2004. Calcium and ROS-mediated activation of transcription factors and TNF- a cytokine gene expression in macrophages exposed to ultrafine particles. Am. J. Physiol. Lung Cell. Mol. Physiol. 286, L344L353.

Casey, A., Davoren, M., Herzog, E., Lyng, F.M., Byrne, H.J., Chambers, G., 2007. Probing the interaction of single walled carbon nanotubes within cell culture medium as a precursor to toxicity testing. Carbon 45, 34-40.

Casey, A., Herzog, E., Lyng, F.M., Byrne, H.J., Chambers, G., Davoren, M., 2008. Single walled carbon nanotubes induce indirect cytotoxicity by medium depletion in A549 lung cells. Toxicol. Lett. 179, 78-84.

Cathcart, R., Schwiers, E., Ames, B.N., 1983. Detection of picomole levels of hydrogenperoxide using a fluorescent dichlorofluorescein assay. Anal. Biochem. 134, 111-116.
Chen, H.W., Su, S.F., Chien, C.T., Lin, W.H., Yu, S.L., Chou, C.C., Chen, J.J., Yang, P.C., 2006. Titanium dioxide nanoparticles induce emphysema-like lung injury in mice. FASEB J. 20, 2393-2395.

Cheng, D., Yang, J., Zhao, Y., 2004. Antibacterial materials of silver nanoparticles application in medical appliances and appliances for daily use. Chin. Med Equip. J. 4, 26-32.

Cho, K.-H., Park, J.-E., et al., 2005. The study of antimicrobial activity and preservative effects of nanoAg ingredient. Electrochim. Acta 51 (5), 956-960.

Choi, O., Clevenger, T.E., Deng, B., Surampalli, R.Y., Ross Jr., L., Hu, Z., 2009. Role of sulfide and ligand strength in controlling nanosilver toxicity. Water Res. 43 (7), 1879-1886.

Clare, M.G., Cormack, H.L., 1996. Can in-vitro assays predict chemically-induced skin damage? Inflammopharmacology 4 (2), 195-204

Cohen, M.S., Stern, J.M., Vanni, A.J., Kelley, R.S., Baumgart, E., Field, D., Libertino, J.A., Summerhayes, I.C., 2007. In vitro analysis of a nanocrystalline silver-coated surgical mesh. Surg. Infect. 8, 397-403.

Cooke, M.C., Evans, M.D., Dizdaroglu, M., Lunec, J., 2003. Oxidative DNA damage: mechanisms, mutation, and disease. FASEB J. 17, 1195-1214.

Crouch, S., Kozlowski, R., Slater, K., Fletcher, J., 1993. The use of ATP bioluminescence as a measure of cell proliferation and cytotoxicity. J Immunol. Methods 160, 81-88.

De Fries, R., Mitsuhashi, M., 1995. Quantification of mitogen induced human lymphocyte proliferation: Comparison of alamarbluetm assay to $3 \mathrm{~h}$-thymidine incorporation assay. J. Clin. Lab. Anal. 9, 89-95.

Donaldson, K., Stone, V., Tran, C.L., Kreyling, W., Borm, P.J.A., 2004. Nanotoxicology. Occup. Environ. Med. 61, 727-728.

Eturska, M., Obreshkova, E., 1979. Argyria in the prolonged use of adsorgan. Vutr Boles. 18, 121-123.

Franken, N.A.P., Rodermond, H.M., Stap, J., Haveman, J., Bree, C.V., 2006. Clonogenic assay of cells in vitro. Nat. Protoc. 1, 2315-2319.

Hussain, S.M., Hess, K.L., et al., 2005. In vitro toxicity of nanoparticles in BRL 3A rat liver cells. Toxicol. In Vitro 19 (7), 975-983.

Kim, S., Choi, J.E., Choi, J., Chung, K.-H., Park, K., Yi, J., Ryu, D.-Y., 2009. Oxidative stress-dependent toxicity of silver nanoparticles in human hepatoma cells. Toxicol. In Vitro 23, 1076-1084.

Lansdown, A.B., 2006. Silver in health care: antimicrobial effects and safety in use Curr. Probl. Dermatol. 33, 17-34.

Lee, H.Y., Park, H.K., Lee, Y.M., Kim, K., Park, S.B., 2007. A practical procedure for producing silver nanocoated fabric and its antibacterial evaluation for biomedical applications. Chem. Commun. (Camb.) 28, 2959-2961.

Liau, S.Y., Read, D.C., et al., 1997. Interaction of Ag nitrate with readily identifiable groups: relationship to the antibacterial action of Ag ions. Lett. Appl. Microbiol 25 (4), 279-283.

Lundqvist, M., Stigler, J., Elia, G., Lynch, I., Cedervall, T., Dawson, K., 2008 Nanoparticle size and surface properties determine the protein corona with possible implications for biological impacts. PNAS 105 14265-14270.

Lynch, I., Dawson, K., 2008. Protein-nanoparticle interactions. Nanotoday 3, 40-47.

Magrez, A., Kasas, S., Sallicio, V., Pasquier, N., Seo, J.W., Celio, M., Catsicas, S., Schwaller, B., Forro, L., 2006. Cellular toxicity of carbon-based nanomaterials. Nano Lett. 6 (6), 1121-1125.

Moaddab, S., Ahari, H., Shahbazzadeh, D., Motallebi, A.A., Anvar, A.A., Rahman-Nya, J., Shokrgozar, M.R., 2011. Toxicity study of nanosilver (nanocid ${ }^{\circledR}$ ) on osteoblast cancer cell line. Int. Nano Lett. 1, 11-16.

Mosmann, T., 1983. Rapid colorimetric assay for cellular growth and survival: application to proliferation and cytotoxicity assays. J. Immunol. Methods 65 (12), 55-63.

Muangman, P., Chuntrasakul, C., Silthram, S., Suvanchote, S., Benjathanung, R. Kittidacha, S., Rueksomtawin, S., 2006. Comparison of efficacy of $1 \%$ silver sulfadiazine and Acticoat for treatment of partial-thickness burn wounds. J. Med. Assoc. Thai. 89, 953-958.

Mukherjee, S.P., Davoren, M., Byrne, H.J., 2010a. In vitro mammalian cytotoxicological study of PAMAM dendrimers - towards quantitative structure activity relationships. Toxicol. In Vitro 24 (1), 1169-1177.

Mukherjee, S.P., Lyng, F.M., Garcia, A., Davoren, M., Byrne, H.J., 2010b. Mechanistic studies of in vitro cytotoxicity of poly(amidoamine) dendrimers in mammalian cells. Toxicol. Appl. Pharmacol. 248 (3), 259-268.

Naha, P.C., Casey, A., Tenuta, T., Lynch, I., Dawson, K.A., Byrne, H.J., Davoren, M. 2009. Preparation, characterization of NIPAM and NIPAM/BAM copolymer nanoparticles and their acute toxicity testing using an aquatic test battery. Aquat. Toxicol. 92, 146-154.

Oberdörster, G., Finkelstein, J.N., Johnston, C., Gelein, R., Cox, C., Baggs, R., Elder A.C.P., 2000. Acute pulmonary effects of ultrafine particles in rats and mice. HE Research Report 96. Health Effects Institute, <http://www.healtheffects.org/ pubs-research.htm>.

O’Brien, J., Wilson, I., Orton, T., Pognan, F., 2000. Investigation of the Alamar Blue (resazurin) fluorescent dye for the assessment of mammalian cell cytotoxicity. Eur. J. Biochem. 267, 5421-5426.

Percival, S.L., Bowler, P.G., Russell, D., 2005. Bacterial resistance to Ag in wound care J. Hosp. Infect. 60, 1-7.

Puck, T.T., Marcus, P.L., 1956. Action of X-rays on mammalian cells. J. Exp. Med. 103 653-666.

Renwick, L.C., Brown, D., Clouter, A., Donaldson, K., 2004. Increased inflammation and altered macrophage chemotactic responses caused by two ultrafine particle types. Occup. Environ. Med. 61, 442-446. 
Shuval, H., Fattal, B., Nassar, A., Lev, O., Pedahzur, R., 1995. The study of the synergism between oligodynamic $\mathrm{Ag}$ and hydrogen peroxide as a long-acting water disinfectant. Water Supply 13, 241-251.

Shvedova, A.A., Kisin, E.R., Mercer, R., Murray, A.R., Johnson, V.J., Potapovich, A.I. Tyurina, Y.Y., Gorelik, O., Arepalli, S., Schwegler-Berry, D., Hubbs, A.F., Antonini, J., Evans, D.E., Ku, B.K., Ramsey, D., Maynard, A., Kagan, V.E., Castranova, V., Baron, P., 2005. Unusual inflammatory and fibrogenic pulmonary responses to single-walled carbon nanotubes in mice. Am. J. Physiol. Lung Cell. Mol. Physiol. 289, L698-L708.

Snow, E.T., Sykora, P., Durham, T.R., Klein, C.B., 2005. Arsenic, mode of action at biologically plausible low doses: What are the implications for low dose cancer risk? Toxicol. Appl. Pharm. 207, S557-S564.

Spencer, W.H., Garron, L.K., Contreras, F., Hayes, T.L., Lai, C., 1980. Endogenous and exogenous ocular and systemic silver deposition. Trans. Ophthalmol. Soc. UK $100,171-178$.

Stennicke, H.R., Jürgensmeier, J.M., Shin, H., Deveraux, Q., Wolf, B.B., Yang, X., Zhou, Q., Ellerby, H.M., Ellerby, L.M., Bredesen, D., Green, D.R., Reed, J.C., Froelich, C.J., Salvesen, G.S., 1998. Pro-caspase-3 Is a Major Physiologic Target of Caspase-8. J. Biol. Chem. 273, 27084-27090.

Tipnis, S.R., Blake, D.G., Shepherd, A.G., McLellan, L.I., 1999. Overexpression of the regulatory subunit of c-glutamylcysteine synthetase in HeLa cells increases c- glutamylcysteine synthetase activity and confers drug resistance. Biochem. J. 337, 559-566.

Valko, M., Izakovic, M., Mazur, M., Rhodes, C.J., Telser, J., 2004. Role of oxygen radicals in DNA damage and cancer incidence. Mol. Cell. Biochem. 266, 37-56.

Van deVoorde, K., Nijsten, T., Schelfhout, K., Moorkens, G., Lambert, J., 2005. Longterm use of silver containing nose-drops resulting in systemic argyria. Acta Clin. Belg. 60, 33-35.

Vigneshwaran, N., Kathe, A.A., Varadarajan, P.V., Nachane, R.P., Balasubramanya, R.H.J., 2007. Functional finishing of cotton fabrics using silver nanoparticles. Nanosci. Nanotechnol. 7, 1893-1897.

Vila, A., Sanchez, A., Tobío, M., Calvo, P., Alonso, M.J., 2002. Design of biodegradable particles for protein delivery. J. Control. Release 78, 15-24.

Xia, T., Kovochich, M., Brant, J., Hotze, M., Sempf, J., Oberley, T., Sioutas, C., Yeh, J.I., Wiesner, M.R., Nel, A.E., 2006. Comparison of the abilities of ambient and manufactured nanoparticles to induce cellular toxicity according to an oxidative stress paradigm. Nano Lett. 6, 1794-1807.

York, J.D., Majerus, P.W., 1994. Nuclear phosphatidylinositols decrease during Sphase of the cell cycle in HeLa cells. J. Biol. Chem. 269, 7847-7850.

Zhang, Y., Sun, J., 2007. A study on the bio-safety for nano-silver as anti-bacterial materials. Chin. J. Med. Instrum. 31, 35-38. 